\title{
International Union of Basic and Clinical Pharmacology. LXXVII. Kisspeptin Receptor Nomenclature, Distribution, and Function
}

Helen R. Kirby, Janet J. Maguire, William H. Colledge, and Anthony P. Davenport

Clinical Pharmacology Unit (H.R.K., J.J.M., A.P.D.) and Reproductive Physiology Group, Department of Physiology, Development and Neuroscience (W.H.C.), University of Cambridge, Cambridge United Kingdom

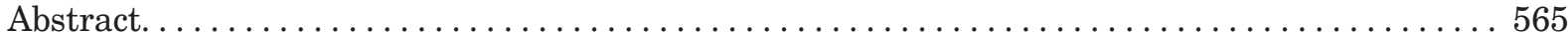

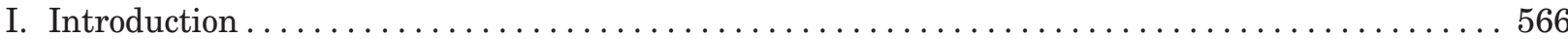

II. G-protein-coupled receptor 54 designated as the kisspeptin receptor. . . . . . . . . . . . . . 566

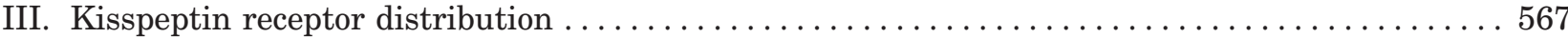

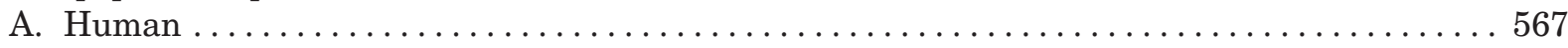

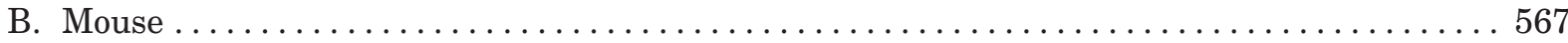

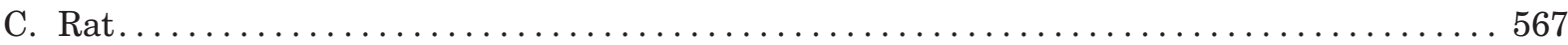

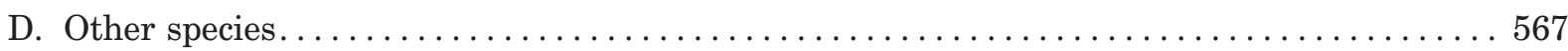

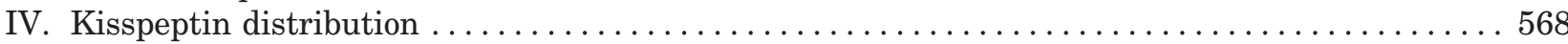

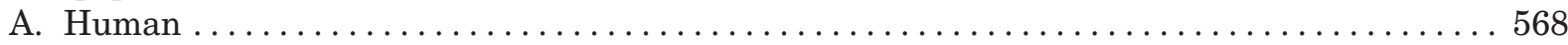

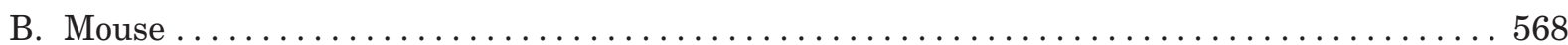

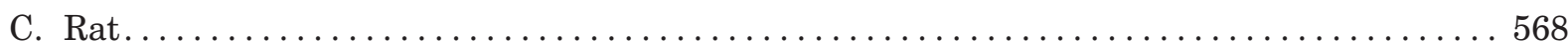

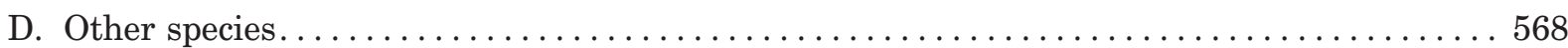

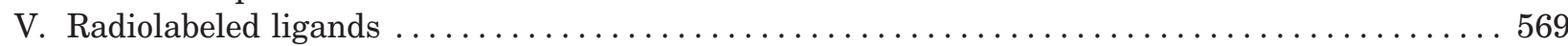

VI. Agonists . . . . . . . . . . . . . . . . . . . . . . . . . . . . . . . . . . . . . . . . . . 569

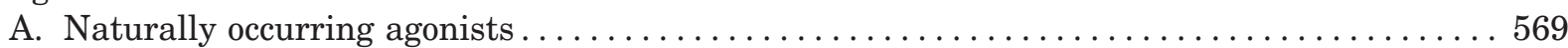

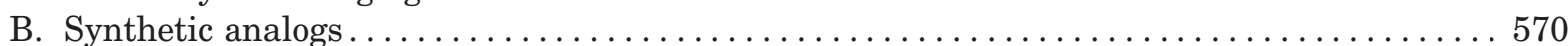

VII. Antagonists . . . . . . . . . . . . . . . . . . . . . . . . . . . . . . . . . . . . . . . 571

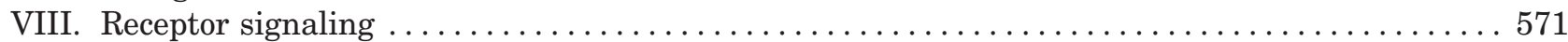

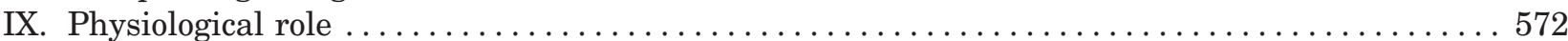

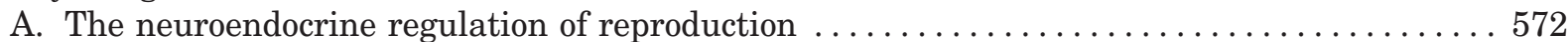

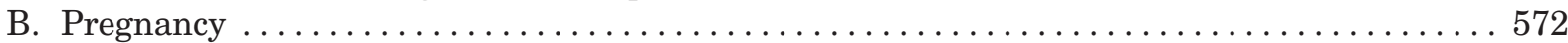

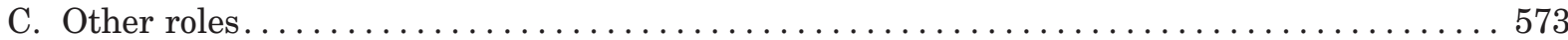

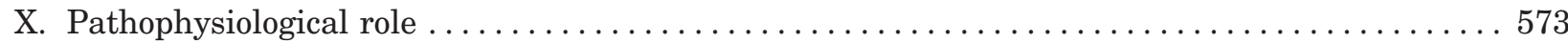

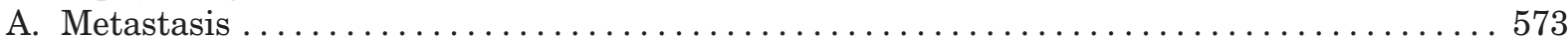

B. Disorders of the hypothalamic-pituitary-gonadal axis $\ldots \ldots \ldots \ldots \ldots \ldots \ldots \ldots \ldots \ldots \ldots 73$

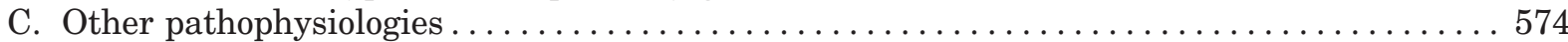

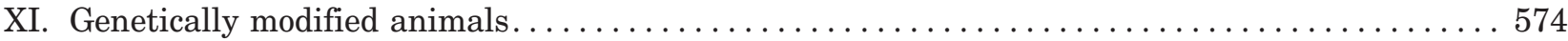

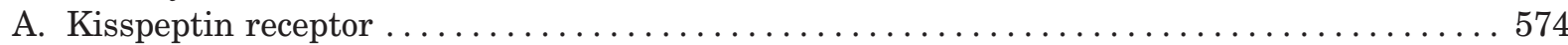

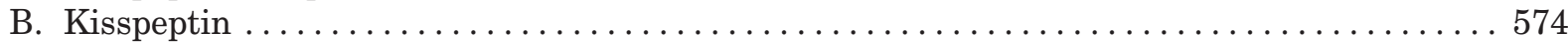

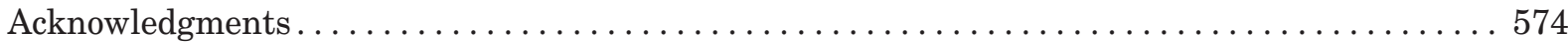

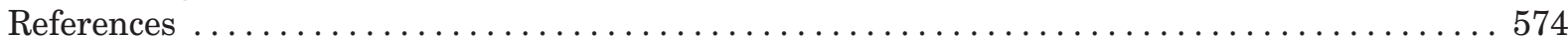

Abstract-Kisspeptins are members of the ArgPhe amide family of peptides, which have been identified as endogenous ligands for a G-protein-coupled receptor encoded by a gene originally called GPR54

Address correspondence to: Dr. Anthony Davenport, on behalf of NCIUPHAR, Emerging Pharmacology Group, Clinical Pharmacology Unit, University of Cambridge, Addenbrookes Hospital, Cambridge., CB2 0QQ, United Kingdom. E-mail: apd10@medschl.cam.ac.uk

This article is available online at http://pharmrev.aspetjournals.org. doi:10.1124/pr.110.002774. (also known as AXOR12 or hOT7T175). After this pairing, the gene has been renamed KISS1R. The International Union of Basic and Clinical Pharmacology Committee on Receptor Nomenclature and Drug Classification recommends that the official name for the receptor is the kisspeptin receptor to follow the convention of naming the receptor protein after the endogenous ligand. The endogenous ligand was initially called metastin, after its role as a metastasis suppressor, and is now referred to as kisspeptin-54 (KP-54), a C-terminally amidated 54- 
amino acid peptide cleaved from the 145 -amino acid gene product. Shorter C-terminal cleavage fragments [KP-14, KP-13 and KP-10 (the smallest active fragment)] are also biologically active. Both receptor and peptide are widely expressed in human, rat, and mouse; the receptor sequence shares more than 80\% homology in these species. Activation of the kisspeptin receptor by kisspeptin is via coupling to $G_{q / 11}$ and the phospholipase $C$ pathway, causing
$\mathrm{Ca}^{2+}$ mobilization. Mutations in the KISS1R gene result in hypogonadotropic hypogonadotropism, and targeted disruption of Kiss $1 \mathrm{r}$ in mice reproduces this phenotype, which led to the discovery of the remarkable ability of the kisspeptin receptor to act as a molecular switch for puberty. In addition to regulating the reproductive axis, the kisspeptin receptor is also implicated in cancer, placentation, diabetes, and the cardiovascular system.

\section{Introduction}

The endogenous ligand of the orphan G-protein-coupled receptor GPR54 was identified in 2001 (Kotani et al., 2001; Muir et al., 2001; Ohtaki et al., 2001) as the product of the KISS1 gene, which was a known metastasis suppressor (Lee et al., 1996; Lee and Welch, 1997a,b). The ligand was initially christened metastin and is now referred to as kisspeptin. The KISS1 gene product consists of 145 amino acids, which is cleaved to produce a C-terminally amidated 54 amino-acid peptide, KP-54. The C-terminal cleavage fragments KP-14, KP13, and KP-10 also possess biological activity, although it is unclear to what extent these peptides are generated endogenously (Fig. 1). Cleavage of the three C-terminal amino acids of kisspeptin by the matrix-metalloproteases 2 and 9 (MMP-2/9) renders the peptide inactive (Fig. 1) (Takino et al., 2003). High expression levels of both receptor and peptide are present in the placenta, with lower levels in the brain, particularly the hypothalamus and the pituitary.

The original interest in the kisspeptin system focused on its effects in cancer. However, in 2003, several persons with hypogonadotropic hypogonadism were identified with mutations in the KISS1R gene (Seminara et al., 2003; de Roux et al., 2003). It has since been elucidated in an increasing number of species that kisspeptin, acting at the kisspeptin receptor, is responsible for the regulation of the reproductive axis by integrating internal and external cues. For more detailed information, the reviews listed in Table 1 should be consulted.

The standard NC-IUPHAR rules of nomenclature state that a receptor is named after its endogenous agonist (Vanhoutte et al., 1996), and therefore we support the suggestion of others that, at the protein level, GPR54 is referred to as the kisspeptin receptor (http:// www.iuphar-db.org/PRODDATABASE/ObjectDisplay Forward?objectId=266, Gottsch et al., 2009). They also suggest abbreviating the kisspeptin receptor to KISS1R; however, the use of the letter $\mathrm{R}$ in the abbreviation is not consistent with NC-IUPHAR nomenclature (Vanhoutte et al., 1996), although it helps to avoid confusion when refer-

\footnotetext{
${ }^{1}$ Abbreviations: AVPV, anteroventral periventricular nucleus; FSH, follicle-stimulating hormone; GnRH, gonadotropin-releasing hormone; KP, kisspeptin; LH, luteinizing hormone; MMP, matrix metalloprotease; NC-IUPHAR, Nomenclature Committee, International Union of Basic and Clinical Pharmacology; PeN, preoptic periventricular nucleus; PLC, phospholipase C.
}

ring to KISS1 peptides. Kisspeptin can also be referred to as KP-54, KP-14, KP-13, or KP-10 depending on the length of the fragment. Gene names should be italicized and, consistent with the Human Genome Organization (HUGO), KISS1R refers to the receptor gene and KISS1 to the peptide gene, with lower case letters used for nonhuman species (Table 2).

\section{G-Protein-Coupled Receptor 54 Designated as the Kisspeptin Receptor}

Lee et al. (1999) cloned a novel G-protein-coupled receptor from rat brain and identified this as a 396-amino acid polypeptide with the expected seven transmembrane domains. Metastin, the peptide product of the KISS1 gene, was identified as the endogenous ligand for GPR54 by three independent groups (Kotani et al., 2001; Muir et al., 2001; Ohtaki et al., 2001). This peptide ligand was initially termed metastin after its ability to inhibit metastasis and was classified as a member of the Arg-Phe (RF)-amide family, a group that also includes PrRP, QRFP, and NPFF (Kutzleb et al., 2005). The KISS1 gene was named for its place of discovery, Hershey, Pennsylvania, home of the "Hershey's Kisses" sweets. The name incorporated "SS" for suppressor sequence, reflecting its metastatic effects. Following International Union of Pharmacology convention to name receptors after their endogenous agonists, GPR54 should be designated the kisspeptin receptor for the ligand kisspeptin (Table 3).

The kisspeptin receptor is a class A G-protein-coupled receptor coupled to $G_{q / 11}$, causing activation of the phospholipase C (PLC) signaling pathway and resultant $\mathrm{Ca}^{2+}$ mobilization (see section VII). Rat and human kisspeptin receptors share $85 \%$ sequence identity, increasing to $98 \%$ in the transmembrane domains, whereas mouse and human share $82 \%$ (Fig. 2). The closest structural relative of the kisspeptin receptor is the galanin receptor $\mathrm{GAL}_{1}$, with $45 \%$ homology; howeverm galanin does not bind to it (Lee et al., 1999) (Fig. 3). $\mathrm{KP}-10$, consisting of the $10 \mathrm{C}$-terminal amino acids of the full sequence, is the minimum fragment length needed to bind and activate the kisspeptin receptor, and it has a potency in vitro similar to that of the full-length 54-amino acid peptide (Kotani et al., 2001), although activities after peripheral delivery in vivo are slightly different (Thompson et al., 2006). 


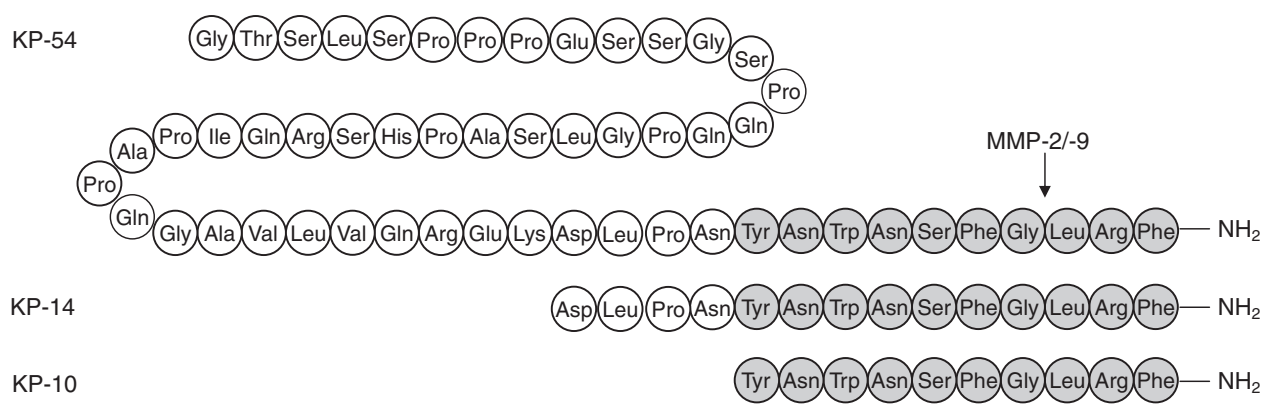

FIG. 1. Human kisspeptin (KP-54) and the cleavage fragments KP-14 and KP-10. The MMP-2/9 cleavage site is indicated.

TABLE 1

Detailed reviews

\begin{tabular}{ll}
\hline \multicolumn{1}{c}{ Focus of Review } & \multicolumn{1}{c}{ Reference } \\
\hline Signalling & Castaño et al., 2009 \\
$\begin{array}{l}\text { Distribution } \\
\text { Function of kisspeptin }\end{array}$ & Oakley et al., 2009 \\
General overview & Mead et al., 2007a \\
Cancer & Harms et al., 2003 \\
Puberty & Messager, 2005a; Kuohung and Kaiser, 2006; Seminara, 2006; Tena-Sempere, 2006b; \\
& Kauffman et al., 2007a; Navarro et al., 2007; Smith and Clarke, 2007; Roa et al., 2009 \\
Seasonal regulation of reproduction & Revel et al., 2007; Clarke et al., 2009; Simonneaux et al., 2009 \\
Metabolic regulation of reproduction & Castellano et al., 2009 \\
Pregnancy & Reynolds et al., 2009 \\
Transgenic mouse models & Colledge, 2009a,b \\
\hline
\end{tabular}

TABLE 2

Nomenclature for kisspeptin and its receptor

\begin{tabular}{llll}
\hline Kisspeptin & \multicolumn{1}{c}{ Species } & \multicolumn{1}{c}{ Gene } & \multicolumn{1}{c}{ Protein } \\
\hline Receptor & Human & KISS1R & Kisspeptin receptor \\
& Nonhuman & Kiss1r & Kisspeptin receptor \\
Peptide & Human & KISS1 & Kisspeptin/KP-54/KP-14/ \\
& & & KP-13/KP-10 \\
& Nonhuman & \multirow{2}{*}{ Kiss1 } & Kisspeptin/KP-54/KP-14/ \\
& & & KP-13/KP-10 \\
\hline
\end{tabular}

\section{Kisspeptin Receptor Distribution}

\section{A. Human}

In humans, reverse transcriptase polymerase chain reaction has revealed high levels of KISS1R mRNA in placenta, pituitary, pancreas, and spinal cord (Kotani et al., 2001; Muir et al., 2001; Ohtaki et al., 2001) (Table 4). Northern blotting detected high KISS1R mRNA peripherally, in the heart, skeletal muscle, kidney, liver, and placenta, and also in regions of the brain (cerebral cortex, putamen, and medulla) and the spinal cord (Clements et al., 2001). Immunohistochemistry confirmed expression in the brain, detecting neuronal expression in the cerebral cortex, thalamus, pons-medulla, and cerebellum (Muir et al., 2001). In the periphery, specific ${ }^{125} \mathrm{I}-\mathrm{KP}-14$ binding was detected in aorta, coronary artery, and umbilical vein (Mead et al., 2007b), suggesting expression of the kisspeptin receptor in the cardiovascular system.

\section{B. Mouse}

In the mouse, Kiss1r mRNA is expressed in the central nervous system (Funes et al., 2003) and particularly in gonadotropin-releasing hormone $(\mathrm{GnRH})$ neurons (Han et al., 2005; Messager et al., 2005b). With the use of $\mathrm{X}$ gal histochemistry, whereby $\beta$-galactosidase was knocked into the Kiss1r gene, expression has been detected in the dentate gyrus of the hippocampus and in both GnRH neurons and cells in the periventricular region of the posterior hypothalamus but not, interestingly, in the rostral part of the third ventricle or arcuate nucleus (Herbison et al., 2010).

\section{Rat}

In rat, Kiss1r mRNA has been detected in brain regions such as the pons, midbrain, thalamus, hypothalamus, hippocampus, amygdala, cortex, frontal cortex, and striatum in addition to peripheral regions such the liver and intestine (Lee et al., 1999). Another study also localized Kiss1r mRNA to areas of the brain, including diagonal band of Broca, medial septum, medial preopticarea, lateral preoptic area, median preoptic nucleus, and anterior and lateral hypothalamus (Irwig et al., 2004). Kiss1r mRNA has also been found in the pituitary (Richard et al., 2008).

\section{Other Species}

Kiss1r mRNA has been detected in the hypothalamus of pig (Li et al., 2008) and monkey (Shahab et al., 2005) and the pituitary of sheep (Smith et al., 2008). There has been recent interest in conservation of the kisspeptin regulation of reproduction during evolution and in keeping with this the kisspeptin receptor has been detected in several fish species, notably in the brain (Parhar et al., 2004; Mohamed et al., 2007; Nocillado et al., 2007; 
TABLE 3

Classification of the kisspeptin receptor

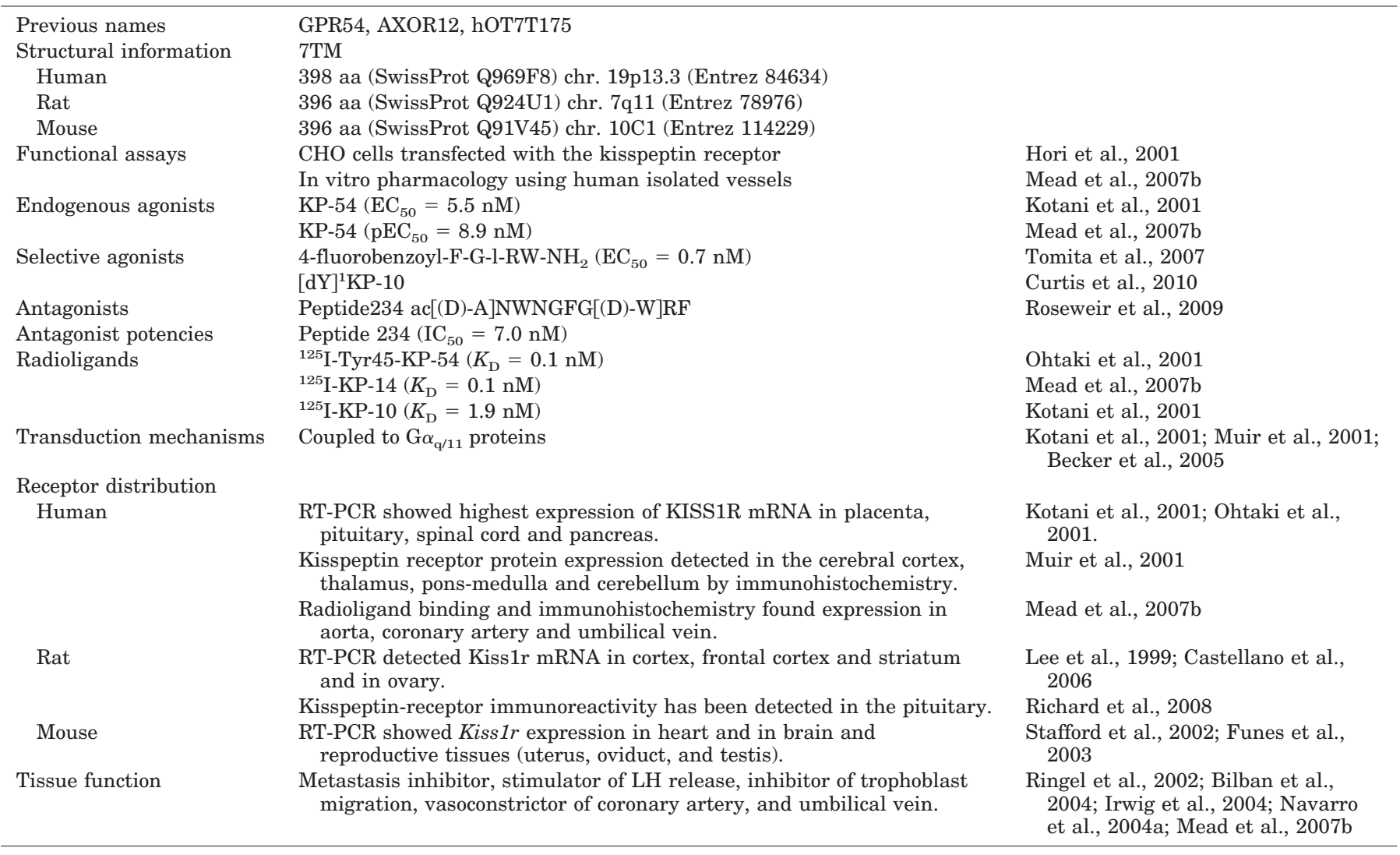

aa, amino acid(s); RT-PCR, reverse transcription-polymerase chain reaction.

Biran et al., 2008; Filby et al., 2008; van Aerle et al., 2008; Carrillo et al., 2009; Li et al., 2009; Mechaly et al., 2009; Yang et al., 2010) and in frog (Lee et al., 2009; Moon et al., 2009).

\section{Kisspeptin Distribution}

\section{A. Human}

KISS1 mRNA showed a similar distribution to the receptor, with high levels in placenta, pancreas, testis, liver, and small intestine (Lee et al., 1996; Muir et al., 2001; Ohtaki et al., 2001). More recently, KISS1 mRNAexpressing neurons within the hypothalamus have been identified by in situ hybridization in the infunidibular nucleus (Rometo et al., 2007), the human equivalent of the arcuate nucleus in animals.

\section{B. Mouse}

Kisspeptin has been detected at both the mRNA and protein level in several hypothalamic nuclei including the anteroventral periventricular nucleus (AVPV), the preoptic periventricular nucleus $(\mathrm{PeN})$, and the arcuate nucleus (Gottsch et al., 2004; Clarkson and Herbison, 2006), areas implicated in the regulation of gonadotropin secretion. It is noteworthy that levels in the AVPV and PeN are 10-fold higher in female mice than in male mice (Clarkson and Herbison, 2006). The distribu- tion of kisspeptin-immunoreactivity in the mouse brain has been mapped using a well characterized polyclonal rabbit anti-kisspeptin-10 antiserum (AC566) (Franceschini et al., 2006), identifying areas of expression in the arcuate nucleus, the rostral part of the third ventricle, including the AVPV region and in the dorsomedial nucleus and posterior hypothalamus (Clarkson et al., 2009).

\section{Rat}

Kiss1 mRNA has been detected in the central nervous system and in particular in specific hypothalamic regions, such as the arcuate nucleus, the AVPV, and the PeN (Irwig et al., 2004; Smith et al., 2006b; Adachi et al., 2007; Kauffman et al., 2007b; Kalamatianos et al., 2008). Kiss1 mRNA expression has also been found in the pituitary (Richard et al., 2008). At the protein level, kisspeptin-like immunoreactivity has been identified in the arcuate nucleus and also in the paraventricular and ventromedial nuclei of the hypothalamus (Brailoiu et al., 2005); however, there is some indication that antisera may cross-react with other RF-amide peptides (Colledge, 2009a,b).

\section{Other Species}

Kisspeptin has been identified in homologous regions of the brain in monkey (Shahab et al., 2005; Shibata et 


\begin{tabular}{|c|c|}
\hline Human & MHTVATSGPNASWGAPANASGCPGCGANASDGPVPSPRAVDAWLVPLFFA \\
\hline Rat & MAAEATLGPNVSWWAFSNASGCPGCGVNASDGPGSAPRPLDAWLVPLFFA \\
\hline Mouse & 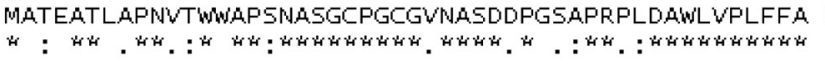 \\
\hline Human & ALMLLGLVGNSLVI $W I C R H K P M R T V T N F Y I A N L A A T D V T F L L C C V P F T A$ \\
\hline Rat & ALMLLGLVGNSLVIFVICRHKHMOTVTNFYIANLAATDVTFLLCCVPFTA \\
\hline Mouse & 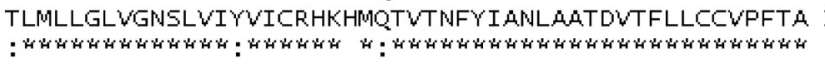 \\
\hline Human & LLYPLPGWVLGDFMCKFVNYIQQVSVOATCATLTAMSVDRWWTVFPLRA \\
\hline Rat & LLYPLPTWVLGDFMCKFVNYIQQVSVQATCATLTAMSVDRWWTVFPLRA \\
\hline Mouse & LLYPLPAWVLGDFMCKFVWYIQQVSVOATCATLTAMSVDRWVTVFPLRA \\
\hline Human & LHRRTPRLALAVSLSIWVGSAAVSAPVLALHRLSPGPRAYCSEAFPSRAL \\
\hline Rat & LHRRTPRLALTVSLSIWVGSAAVSAPVLALHRLSPGPHTYCSEAFPSRAL \\
\hline Mouse & 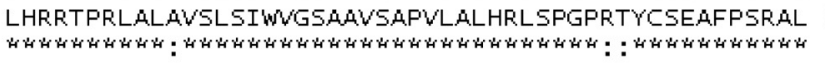 \\
\hline Human & ERAFALYNLLALYLLPLLATCACYAAMLRHLGRVAVRPAPADSALQGQVL \\
\hline Rat & ERAFALYNLLALYLLPLLATCACYGAMLRHLGRAAVRPAPTDGALQGQLL \\
\hline Mouse & 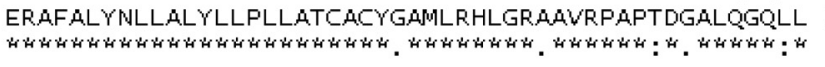 \\
\hline Human & AERAGAVRAKVSRLVAAWLLFAACWGPIQLFLVLQALGPAGSWHPRSYA \\
\hline Rat & AQRAGAVRTKVSRLVAAWLLFAACWGPIQLFLVLQALGPSGAWHPRSYA \\
\hline Mouse & 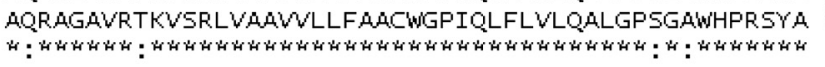 \\
\hline Human & AYALKTWAHCMSYSNSALNPLLYAFLGSHFRQAFRRVCPCAPRRPRRPRR \\
\hline Rat & AYALKIWAHCMSYSNSALNPLL YAFLGSHFRQAFCRVCPCGPQRQRRPHA \\
\hline Mouse & 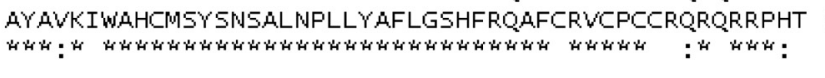 \\
\hline Human & APARAOKPGSSGLAARGLCVLG \\
\hline Rat & SAHSDRAAPHSVPHSRAAHPVRVRTPEPGNP--VRRSPSVQDEHTAPL 3 \\
\hline Mouse & 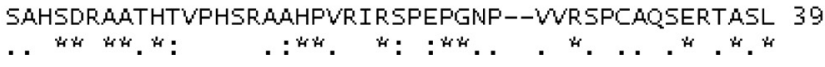 \\
\hline
\end{tabular}

FIG. 2. ClustalW (http://www.ebi.ac.uk/clustalw/) sequence alignment of the human, rat and mouse kisspeptin receptor. *, identical amino acid in both species; :, conserved amino acid substitution; ', semiconserved amino acid substitution; -, break in the sequence.

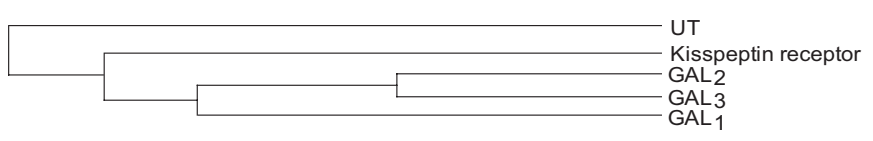

FIG. 3. Cladogram showing the relationship of the kisspeptin receptor with other receptors. UT, urotensin receptor; $\mathrm{GAL}_{1-3}$, galanin receptors.

al., 2007; Ramaswamy et al., 2008, 2009), sheep (Estrada et al., 2006; Franceschini et al., 2006; Pompolo et al., 2006), horse (Decourt et al., 2008; Magee et al., 2009), hamster (Paul et al., 2009), goat (Ohkura et al., 2009, and pig (Tomikawa et al., 2010). Kisspeptin has also been found to be expressed in frog (Lee et al., 2009) and fish species (Biran et al., 2008; Felip et al., 2008; Kanda et al., 2008; van Aerle et al., 2008; Carrillo et al., 2009; Kitahashi et al., 2009; Li et al., 2009; Yang et al., 2010), suggesting that the kisspeptin system has been conserved during evolution.

\section{Radiolabeled Ligands}

Saturation binding analysis, in cells artificially expressing either human or rat KISS1R, has been used to determine dissociation constant, $K_{\mathrm{D}}$, values for ${ }^{125} \mathrm{I}-$ Tyr45-KP-15 (95 pM, human) (Ohtaki et al., 2001) and ${ }^{125} \mathrm{I}-\mathrm{KP}-10(1.9 \pm 0.4 \mathrm{nM}$, human; $1.0 \pm 0.1 \mathrm{nM}$, rat $)$ (Kotani et al., 2001). ${ }^{125} \mathrm{I}-\mathrm{KP}-14$ has been characterized in human cardiovascular tissues, where it bound saturably, specifically, and reversibly in human aorta with a $K_{\mathrm{D}}$ of $0.20 \pm 0.03 \mathrm{nM}$ and a binding density, $B_{\max }$, of $7.65 \pm 0.95 \mathrm{fmol} / \mathrm{mg}$ protein. Binding had an association rate constant $\left(k_{\text {obs }}\right)$ of $0.164 \pm 0.054 \mathrm{~min}^{-1}$, a dissociation rate constant of $0.0020 \pm 0.0006 \mathrm{~min}^{-1}$, a half-time $\left(t_{1 / 2}\right)$ for association of $4 \mathrm{~min}$, and $t_{1 / 2}$ for dissociation of $301 \mathrm{~min}$ (Mead et al., 2007b). Both KP-10 and KP-14 competed monophasically for ${ }^{125}$ I-kisspeptin-14 binding with $K_{\mathrm{D}}$ values of $0.03 \pm 0.007$ and $0.26 \pm 0.12 \mathrm{nM}$, respectively, suggesting that, together with the Hill slope of $1.12 \pm 0.09$, there is only one receptor for kisspeptin despite the potential multiple endogenous peptides. Iodinated KP-54 has also been synthesized and used in radioimmunoassays (Dhillo et al., 2005).

\section{Agonists}

\section{A. Naturally Occurring Agonists}

$\mathrm{KP}-54$, the long isoform of kisspeptin in human, is predicted to be cleaved from the C-terminally amidated KP-145 precursor by furin or prohormone convertases, deduced by the presence of pairs of basic residues flanking this sequence (Kotani et al., 2001; Ohtaki et al., 2001; Harms et al., 2003). The original report describing the isolation of KISS1 mRNA contained a sequencing 
TABLE 4

Summary of the distribution of KISS1R mRNA in human compiled from various studies

\begin{tabular}{|c|c|c|c|c|}
\hline Tissue & Ohtaki et al. (2001) & Muir et al. (2001) & Kotani et al. (2001) & Clements et al. (2001) \\
\hline Adrenal gland & N.D. & N.D. & - & N.D. \\
\hline Brain & ++ & N.D. & + & +++ \\
\hline Amygdala & N.D. & +++ & +++++ & N.D. \\
\hline Caudate nucleus & N.D. & +++ & ++++ & N.D. \\
\hline Cerebellum & N.D. & + & ++ & +++ \\
\hline Cerebral cortex & N.D. & N.D. & N.D. & +++ \\
\hline Cingulate gyrus & N.D. & ++++ & N.D. & N.D. \\
\hline Corpus callosum & N.D. & N.D. & ++ & N.D. \\
\hline Globus pallidus & N.D. & +++ & N.D. & N.D. \\
\hline Hippocampus & N.D. & +++ & +++++ & + \\
\hline Hypothalamus & N.D. & +++ & N.D. & N.D. \\
\hline Locus ceruleus & N.D. & +++ & N.D. & N.D. \\
\hline Medial frontal gyrus & N.D. & ++ & N.D. & N.D. \\
\hline Medulla oblongata & N.D. & +++ & N.D. & +++ \\
\hline Nucleus accumbens & N.D. & +++++ & N.D. & N.D. \\
\hline $\begin{array}{l}\text { Parahippocampal } \\
\text { nucleus }\end{array}$ & N.D. & +++ & N.D. & N.D. \\
\hline Putamen & N.D. & +++ & N.D. & +++ \\
\hline Striatum & N.D. & ++ & N.D. & N.D. \\
\hline Substantia nigra & N.D. & ++ & +++++ & N.D. \\
\hline Superior frontal gyrus & N.D. & +++ & N.D. & N.D. \\
\hline Thalamus & N.D. & ++ & ++++ & + \\
\hline Breast & + & N.D. & N.D. & N.D. \\
\hline Bone marrow & + & N.D. & N.D. & N.D. \\
\hline Colon & + & N.D. & N.D. & - \\
\hline Heart & + & N.D. & + & +++ \\
\hline Fetal brain & N.D. & N.D. & ++ & N.D. \\
\hline Fetal liver & N.D. & N.D. & ++ & N.D. \\
\hline Kidney & + & N.D. & + & +++ \\
\hline Liver & N.D. & N.D. & - & +++ \\
\hline Lung & + & N.D. & + & + \\
\hline Lymph node & ++ & N.D. & N.D. & N.D. \\
\hline Ovary & + & N.D. & N.D. & N.D. \\
\hline Pancreas & +++++ & N.D. & +++++ & N.D. \\
\hline Peripheral blood leukocyte & ++ & N.D. & N.D. & + \\
\hline Pituitary & N.D. & N.D. & ++++ & N.D. \\
\hline Placenta & ++++ & N.D. & +++++ & +++ \\
\hline Prostate & + & N.D. & N.D. & N.D. \\
\hline Spinal cord & N.D. & + & ++++ & +++ \\
\hline Skeletal muscle & - & N.D. & - & +++ \\
\hline Small intestine & + & N.D. & N.D. & - \\
\hline Spleen & ++ & N.D. & + & + \\
\hline Testis & ++ & N.D. & + & N.D. \\
\hline Thymus & + & N.D. & ++ & - \\
\hline Tonsil & + & N.D. & N.D. & N.D. \\
\hline Stomach & N.D. & N.D. & + & N.D. \\
\hline
\end{tabular}

N.D., tissue not included in the study; -, expression not detected as; + to +++++ , levels of expression graded from low expression to high.

error (Lee et al., 1996) that introduced a frameshift mutation at amino acid 46 in the precursor peptide and led to a prediction that the resultant protein would consist of 164 amino acids. The corrected sequence, and the corresponding shorter open reading frame of 145 amino acids, was subsequently published (West et al., 1998). In rat and mouse, the long kisspeptin isoform is 52 amino acids long, with Arg-Try- $\mathrm{NH}_{2}$ at the $\mathrm{C}$ terminus instead of Arg-Phe- $\mathrm{NH}_{2}$ as in humans (Tena-Sempere 2006a).

Shorter isoforms of kisspeptin, consisting of the 10-, 13-, and 14-amino acid amidated C-terminal sequences, also possess biological activity and have been shown to have potency similar to that of the longer form in vitro (Mead et al., 2007b; Mikkelsen et al., 2009), although a discrepant report exists (Pheng et al., 2009). The shorter isoforms have been reported to have a lower potency in vivo than KP-54 (Thompson et al., 2009), possibly as a result of increased susceptibility to degradation in the circulation. Is it currently not known which of the isoforms of kisspeptin are endogenous or whether the shorter forms are breakdown products, although KP-54, $\mathrm{KP}-14$, and KP-13 have been detected in human placenta (Kotani et al., 2001) and KP-54 in plasma of pregnant women (Horikoshi et al., 2003; Dhillo et al., 2006). In cells artificially expressing the human kisspeptin receptor, KP-13, KP-14, and KP-54 bound with equal affinity (Kotani et al., 2001), and this is reflected in equipotent function of isoforms in native human tissue (Mead et al., 2007b).

\section{B. Synthetic Analogs}

A number of studies have attempted to identify the residues that are necessary and sufficient to activate the kisspeptin receptor. Alanine and D-amino acid scans revealed that the five C-terminal amino acids of KP-10 are crucial for agonist activity (Niida et al., 2006). The pharmacophore site has been identified as Phe9, Arg12, 
and Phe13 of KP-13 (Orsini et al., 2007), with the peptide forming a helicoid conformation from Asn7 to Phe13. The extreme $\mathrm{C}$ terminus, the RF moiety, of the receptor seems to be evolutionarily conserved, suggesting that this motif is essential for receptor binding, in agreement with the role of these residues as a pharmacophore. In rat, alanine substitution indicated that residues 6 and 10 of KP-10 are essential for kisspeptin receptor activation, at least in this species (GutiérrezPascual et al., 2009).

The synthesis of lower molecular weight derivatives of the KP-10 structure by 9-fluorenylmethoxycarbonylbased solid-phase peptide synthesis produced molecules, such as the pentapeptide H-Amb-Nal(2)-Gly-Leu-ArgTrp- $\mathrm{NH}_{2}$, that were high-potency agonists comparable with kisspeptin (Tomita et al., 2006). Further investigations into the effect of terminal acyl groups on agonist potencies of pentapeptide analogs led to the synthesis of 4-fluorobenzoyl-Phe-Gly-Leu-Arg-Trp- $\mathrm{NH}_{2}$, with an $\mathrm{EC}_{50}$ of $0.69 \mathrm{nM}$ (Tomita et al., 2007). Agonistic peptide analogs of this compound have been synthesized that were more stable against degradation by MMP-2 and -9 (Tomita et al., 2008), which should prove useful in increasing in vivo stability.

A recent structure-activity study revealed that the five N-terminal amino acids of KP-10 are required for receptor activation and also identified key residues, Ser5 and Leu8, that are obligatory for agonist activity. They also found that analogs comprising five amino acids possessed lower binding affinities than those containing the full 10 residues (Roseweir et al., 2009). In addition, a KP-10 analog, $[\mathrm{dY}]^{1} \mathrm{KP}-10$, has been reported to be a superagonist in mice in vivo (Curtis et al., 2010). However, previous work by Niida et al. (2006) found no stimulation of the kisspeptin receptor with this analog, which could be due to differences in reporter systems in the two studies.

\section{Antagonists}

One peptide antagonist has been reported: ac[(D)A]NWNGFG[(D)-W]RF (peptide 234) (Roseweir et al., 2009). It was discovered by systematically substituting amino acid residues in the KP-10 sequence and the resulting compounds were tested for the ability to inhibit kisspeptin-stimulated inositol phosphate release against chinese hamster ovary cells stably expressing the kisspeptin receptor. Peptide 234 contained seven residues conserved from $\mathrm{KP}-10$, had an $\mathrm{IC}_{50}$ of $7.0 \mathrm{nM}$, and competed for the binding of ${ }^{125} \mathrm{I}-\mathrm{KP}-10$ with an affinity of $2.7 \mathrm{nM}$. It was initially demonstrated to inhibit KP-10 actions on the hypothalamic-gonadotropic axis in female rhesus monkeys, male rats, and ovariectomized ewes upon acute central injections. However, recent studies have documented that both intracerebroventricular and systemic administration of a penetratinpeptide 234 fusion molecule are capable of suppressing gonadotropin secretion after central administration of KP-10 to male rats (Pineda et al., 2010).

\section{Receptor Signaling}

At present, knowledge of intracellular signaling pathways downstream of the kisspeptin receptor has mainly come from assays in cell lines. There is substantial evidence that the kisspeptin receptor couples to the $\mathrm{G} \alpha_{\mathrm{q} / 11}$ signaling pathway, activating PLC, to result in phosphatidylinositol 4,5-bisphosphate hydrolysis followed by accumulation of inositol-(1,4,5)-triphosphate and diacylglycerol to cause subsequent $\mathrm{Ca}^{2+}$ mobilization (Kotani et al., 2001; Muir et al., 2001; Ohtaki et al., 2001). Other signaling pathways activated seem to be cell type-dependent, and proposed downstream mediators include protein kinase $\mathrm{C}$, arachidonic acid, mitogen activated protein kinases (such as extracellular signal-regulated kinase 1/2 and p38), and phosphatidylinositol-3-kinase/ Akt (Kotani et al., 2001; Muir et al., 2001; Ringel et al., 2002; Becker et al., 2005; Stathatos et al., 2005). Signaling through inositol-(1,4,5)-triphosphate is also consistent with the potential vasoconstrictor role of kisspeptin (see section VIII.C). It is noteworthy that confirmation of kisspeptin signaling via PLC and $\mathrm{Ca}^{2+}$-dependent pathways has been obtained from studies on $\mathrm{GnRH}$ neurons in brain slices (Castellano et al., 2006b; Liu et al., 2008), which have also shown involvement of transient receptor potential cation channels (Zhang et al., 2008).

Activation of the kisspeptin receptor by kisspeptins also causes phosphorylation of focal adhesion kinase and paxillin, leading to formation of focal adhesion and stress fibers (Kotani et al., 2001; Ohtaki et al., 2001), and this correlates with the role of kisspeptin in inhibiting chemotaxis. Kisspeptin receptor stimulation has been demonstrated to inhibit calcineurin activity (Stathatos et al., 2005), which could also contribute to metastasis suppression. The kisspeptin receptor pathway seems to have the ability to disrupt signaling via the chemokine receptor CXCR4, thus inhibiting the prometastatic activity arising from interaction with its ligand, stromal cell-derived factor 1 (Navenot et al., 2005). Kisspeptin has been reported to induce apoptosis in cells, although there are conflicting reports about the role apoptosis may play in the metastasis-suppressing actions of kisspeptin (Harms et al., 2003; Becker et al., 2005). However, recent evidence favors an involvement of apoptosis (Navenot et al., 2009b), possibly by activation of Rho and Rho-associated kinase (Navenot et al., 2009a).

Desensitization of the hypothalamic-pituitary-gonadal axis after continuous administration of kisspeptin has been demonstrated (Seminara et al., 2006; Thompson et al., 2006; Ramaswamy et al., 2007; Roa et al., 2008a). Further investigation revealed the kisspeptin receptor to be constitutively associated with the G-protein-coupled receptor serine/threonine kinases and $\beta$-arrestins- 1 
and -2 , suggesting that they mediate kisspeptin receptor signaling and desensitization (Pampillo et al., 2009).

The precise mechanism responsible for the inhibitory action of kisspeptin on the expression of MMP-2/9 is not known. However, it is proposed that kisspeptin receptor activation decreases the binding of $\mathrm{NF}_{\kappa} \mathrm{B}$ binding to the promoter region of MMP-9, affecting its expression and resultant cell migration (Yan et al., 2001).

\section{Physiological Role}

\section{A. The Neuroendocrine Regulation of Reproduction}

The crucial role that kisspeptin and its receptor play in the regulation of the reproductive axis was first indicated by observations of loss-of-function mutations in the kisspeptin receptor in some patients with idopathic hypogonadotropic hypogonadism (Seminara et al., 2003; de Roux et al., 2003) and confirmed in transgenic mice models (Funes et al., 2003; Seminara et al., 2003; Kauffman et al., 2007c; Lapatto et al., 2007). Kisspeptin has since been identified as a major regulator of the hypothalamic-pituitary-gonadal axis, governing pubertal onset, in an increasing number of species. Kisspeptin is able to stimulate gonadotropin release in humans (Dhillo et al., 2005, 2007), mice (Gottsch et al., 2004; Messager et al., 2005b), rats (Navarro et al., 2004a, 2005a,b; Thompson et al., 2004, 2006), monkeys (Plant et al., 2006; Seminara, 2006), and sheep (Messager et al., 2005b; Caraty et al., 2007). GnRH is a direct mediator of this effect, as shown in monkeys (Keen et al., 2008), sheep (Messager et al., 2005b), pigs (Lents et al., 2008), and goats (Hashizume et al., 2010). GnRH antagonists are able to block kisspeptin-induced release of gonadotropins (Gottsch et al., 2004; Matsui et al., 2004; Navarro et al., 2004a). Further investigations have shown GnRH neurons to express the kisspeptin receptor (Irwig et al., 2004; Parhar et al., 2004; Han et al., 2005; Messager et al., 2005b) and key experiments involving Kiss1r and Kiss1 knockout mice highlighted that a functional kisspeptin receptor is necessary for GnRH secretion and release of luteinizing hormone ( $\mathrm{LH})$ and folliclestimulating hormone (FSH) (Seminara et al., 2003; Dungan et al., 2007; Lapatto et al., 2007; d'Anglemont de Tassigny et al., 2007, 2008). Investigations into the mechanism of communication between kisspeptin and $\mathrm{GnRH}$ neurons have found that GnRH neuronal activity is increased by kisspeptin, as measured by c-Fos immunoreactivity (Irwig et al., 2004; Matsui et al., 2004), and that kisspeptin depolarizes GnRH neurons (Han et al., 2005; Zhang et al., 2008), increasing firing rates (Quaynor et al., 2007; Dumalska et al., 2008; Liu et al., 2008; Pielecka-Fortuna et al., 2008).

Within the hypothalamus, regulation of the expression of Kiss1 and, to a lesser extent, Kiss1r mRNA by sex steroids has been documented in a range of species. Gonadectomized mice, sheep, and rhesus monkeys show increased Kiss1 mRNA expression in the arcuate nu- cleus or infundibular region (Irwig et al., 2004; Navarro et al., 2004a; Pompolo et al., 2006 Smith et al., 2005a,b, 2007; Rometo et al., 2007 Shibata et al., 2007). Sex steroid replacement decreases the elevated Kiss1 mRNA expression to control levels (Navarro et al., 2004a; Smith et al., 2005b, 2007; Pompolo et al., 2006; Rometo et al., 2007; Shibata et al., 2007), suggesting that this circuitry represents negative feedback control of gonadotropin secretion. Conversely, the preovulatory LH surge involves positive feedback; in mice and rats, this seems to be regulated by neurons in the AVPV (Smith et al., 2005a, 2006b; Adachi et al., 2007). Ovariectomized female rats have decreased Kiss 1 mRNA expression in the AVPV, which is restored with estrogen replacement (Smith et al., 2005a). This seems to be mediated by the estrogen receptor ER $\alpha$ (Kinoshita et al., 2005; Adachi et al., 2007; Roa et al., 2008b,c). However, this mechanism of control varies between species; in sheep and primates, kisspeptin neurons are restricted to the arcuate nucleus and the preoptic area, and both positive and negative feedback regulation of gonadotropin secretion seems to occur in the arcuate nucleus (Estrada et al., 2006; Pompolo et al., 2006; Smith et al., 2007).

There is substantial evidence that kisspeptin receptor signaling is required for the initiation of puberty. Humans and mice with disruption of the KISS1R or KISS1 gene fail to go through puberty (de Roux et al., 2003; Funes et al., 2003; Seminara et al., 2003; d'Anglemont de Tassigny et al., 2007; Lapatto et al., 2007). Kisspeptin administration induced precocious puberty (Navarro et al., 2004b), whereas central injection of a kisspeptin antagonist delayed puberty (Pineda et al., 2010), in prepubertal rats. During puberty, there seems to be increased communication between kisspeptin and GnRH neurons, demonstrated by increased hypothalamic Kiss1 and Kiss1r mRNA expression in rats and monkeys (Navarro et al., 2004a; Shahab et al., 2005), increased appositions between kisspeptin fibers and GnRH neurons (Clarkson and Herbison, 2006), increased kisspeptin pulse frequency (Keen et al., 2008), and increased sensitivity of GnRH neurons to kisspeptin (Han et al., 2005). Kisspeptin may also act at the level of the pituitary, although this is controversial and warrants further investigation (Richard et al., 2009).

A growing body of evidence suggests that the kisspeptin/kisspeptin receptor system has the ability to integrate both metabolic cues, such as nutritional status and metabolism (Castellano et al., 2005; Smith et al., 2006a), and environmental cues such as photoperiod (Greives et al., 2007; Revel et al., 2007; Smith et al., 2007; Wagner et al., 2008) and act on these to affect the reproductive system.

\section{B. Pregnancy}

In addition to the well established role of kisspeptin and its receptor in the regulation of the reproductive axis, the kisspeptin system has been proposed to have effects on other physiological systems, such as gestation. 
Initial reports of kisspeptin expression reported high levels in the human placenta (Lee et al., 1996; Muir et al., 2001; Ohtaki et al., 2001). More specifically, kisspeptin and kisspeptin receptor expression has now been demonstrated in human trophoblasts (Janneau et al., 2002; Bilban et al., 2004), with higher expression in the first trimester than the third, correlating with decreasing invasiveness. An in-house validated radioimmunoassay revealed that in male and nonpregnant female humans, plasma kisspeptin circulates at very low concentrations (Dhillo et al., 2005, 2006). However, during pregnancy, plasma kisspeptin concentrations increase dramatically, with a 1000 -fold increase in the first trimester, rising to a 10,000-fold increase in the third trimester (Horikoshi et al., 2003). Kisspeptin inhibits the migration of trophoblasts, at least in vitro (Bilban et al., 2004), possibly via down-regulation of MMP-2. Kiss1 and Kiss1r mRNA expression has also been detected in the trophoblast giant cells of the rat placenta (Terao et al., 2004), although the relevance of kisspeptin in the physiology of gestation of nonhuman species has yet to be fully investigated.

\section{Other Roles}

In the human cardiovascular system, expression of both receptor and peptide has been identified in the coronary artery, aorta, and umbilical vein, and kisspeptin elicited potent vasoconstrictor effects in coronary artery and umbilical vein (Mead et al., 2007b). In addition, kisspeptin acts as a positive inotropic agent in human and mouse heart (Kirby et al., 2008), consistent with the ability of kisspeptin to increase intracellular $\mathrm{Ca}^{2+}$ (see section VI). This suggests it may function as a cardiovascular transmitter.

In the pancreas, high expression of peptide and receptor has been detected in human and mouse islet endocrine cells, where it can potentiate the secretion of insulin (Hauge-Evans et al., 2006; Bowe et al., 2009). Additional studies suggested that intravenous KP-10 increased insulin levels in rats (Bowe et al., 2009, although another group found that KP-13 reduced glucose-induced insulin secretion in a perfused-pancreas model (Silvestre et al., 2008), a discrepancy that may reflect the different peptides used or the importance of the in vivo environment.

Kiss1 and Kiss1r mRNA have been identified in the rat hippocampus (Arai et al., 2005) and have been shown to affect neuronal transmission there (Arai and Orwig, 2008), presenting the possibility that the kisspeptin system could be involved in neurogenesis, cognition, and the pathogenesis of epilepsy.

\section{Pathophysiological Role}

\section{A. Metastasis}

The initial discovery of kisspeptin was made from observations of an antimetastatic effect of chromosome 6 in human melanoma cell lines (Welch et al., 1994; Miele et al., 1996, 2000). Investigations by subtractive hybridization and differential display showed one gene in particular to be unregulated in those cells transfected with chromosome 6 and that this gene was a metastasis suppressor (Lee et al., 1996; Lee and Welch, 1997a). However, mapping showed that this gene was in fact located on chromosome 1q32, not 6 (Lee et al., 1996). Further studies have determined the presence of a trans-acting regulatory product on chromosome 6 (Lee et al., 1996; West et al., 1998; Goldberg et al., 2003; Mitchell et al., 2007).

The metastatic suppressor activity of the kisspeptin system was first identified in melanoma (Lee and Welch, 1997a; Ohtaki et al., 2001; Shirasaki et al., 2001). It was then shown that this effect was not solely limited to this cancer type by detection in breast cancer (Lee and Welch, 1997b; Martin et al., 2005; Stark et al., 2005; Kostadima et al., 2007; Marot et al., 2007; Mitchell et al., 2007). Most reports associated loss of KISS1 with increasing cancer progression and metastases, although there are contradictions (Martin et al., 2005; Marot et al., 2007). To date, the metastasis suppressor activity of the kisspeptin system has been identified in thyroid (Ringel et al., 2002; Stathatos et al., 2005), ovarian (Jiang et al., 2005; Zhang et al., 2005; Gao et al., 2007; Hata et al., 2007), bladder (Sanchez-Carbayo et al., 2003), gastric (Dhar et al., 2004; Guan-Zhen et al., 2007; Yao et al., 2007), esophageal (Ikeguchi et al., 2004), hepatocellular (Ikeguchi et al., 2003; Hou et al., 2007; Schmid et al., 2007), pancreatic (Masui et al., 2004; Liang and Yang, 2007), and lung (Zohrabian et al., 2007) cancers.

\section{B. Disorders of the Hypothalamic-Pituitary-Gonadal Axis}

An understanding of the fundamental role played by the kisspeptin receptor in puberty was achieved from studies of patients with idiopathic hypogonadotropic hypogonadism. Linkage analysis of these patients, who displayed no sexual maturation and low levels of gonadotropins, revealed mutations in the KISS1R gene: a homozygous substitution of leucine to serine at nucleotide 148 (L148S) or heterozygous mutations at nucleotides 331 (R331X) and 399 (X399R) (Seminara et al., 2003). Since then, other loss-of-function mutations have been documented, and more detailed molecular analysis has shown the L148S mutation to inhibit the catalytic activation of $\mathrm{G}_{\mathrm{q}}$ but not to affect the trafficking, plasma membrane expression, or ligand binding properties of the receptor (Wacker et al., 2008). A gain-of-function mutation (R386P) has been reported in a girl with central precocious puberty (Teles et al., 2008). The mutations in the kisspeptin receptor that are currently known are illustrated in Fig. 4. It is noteworthy that the phenotype observed in humans carrying loss-of-function mutations was mimicked in Kiss1r-null mice (Seminara 


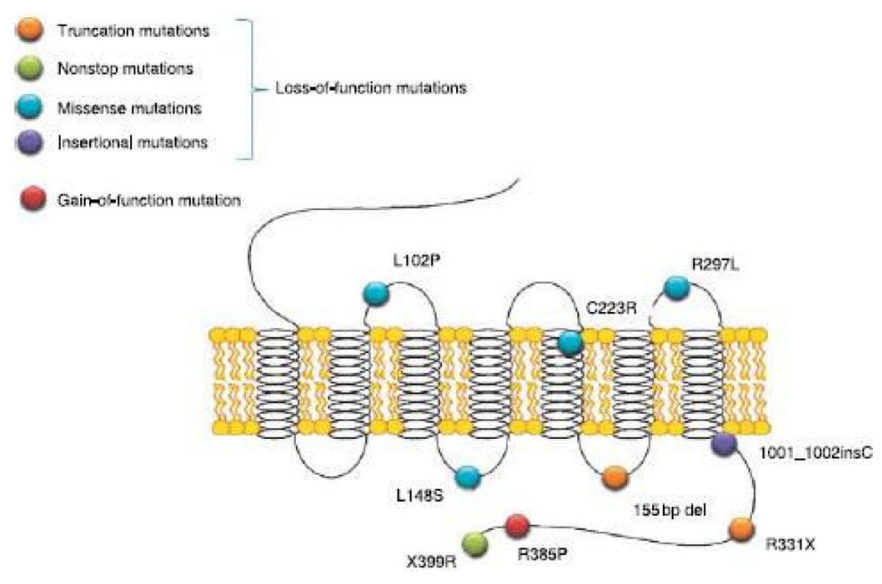

FIG. 4. Identified mutations in the human KISS1R gene. [Reprinted from Gianetti E and Seminara S (2008) Kisspeptin and KISS1R: a critical pathway in the reproductive system. Reproduction 136:295-301. Copyright (C) 2008 Society for Reproduction and Fertility. Used with permission.]

et al., 2003), confirming the essential role of the kisspeptin receptor in pubertal development.

\section{Other Pathophysiologies}

In concordance with the proposed role of the kisspeptin system in pregnancy, there are emerging, although contradictory, reports of changes in kisspeptin expression in preeclampsia (Qiao et al., 2005; Farina et al., 2006; Armstrong et al., 2009). In addition, Panidis et al. (2006) reported raised levels of KP-54 in normal-weight subjects with polycystic ovary syndrome, which correlates with its association with leptin and obesity. However, these results should be interpreted with caution owing to the different assays used. Kisspeptin and kisspeptin receptor expression has also been detected in human atherosclerotic plaques (Mead et al., 2007b).

In diabetes, where hypogonadism is common, disturbed kisspeptin function can be rescued by leptin (Castellano et al., 2006a). The link between leptin and kisspeptin was further strengthened by observations that leptin can influence the expression of kisspeptin in the arcuate nucleus of mice (Smith et al., 2006a).

\section{Genetically Modified Animals}

\section{A. Kisspeptin Receptor}

Disruption of the Kiss1r gene in mice results in viable homozygous offspring with hypogonadotropic hypogonadism. Male mice show small testes, hypoplastic Leydig cells, spermatogenic arrest, and absence of development of secondary sex glands. Female mice have delayed vaginal opening, hypoplastic uterine horns, and small ovaries with no graafian follicles or corpora lutea. Both sexes display decreased levels of sex steroids (testosterone or $\beta$-estradiol) in addition to reduced concentrations of LH and FSH (Funes et al., 2003; Seminara et al., 2003; Kauffman et al., 2007c; Lapatto et al., 2007), and female mice lack the compensatory rise in $\mathrm{LH}$ that usu- ally follows ovariectomy (Dungan et al., 2007). There is also a lack of stimulation of LH or FSH release upon injection of kisspeptin (Messager et al., 2005b). This phenotype is consistent with that of humans with mutations in the KISS1R gene.

\section{B. Kisspeptin}

Targeted disruption of the Kiss1 gene also results in viable offspring who have an inability to undergo sexual maturation. Mutant male mice have arrested spermatogenesis and small testes; female mice have small ovaries, threadlike uteri, and no progression through the estrous cycle; and both sexes have low levels of circulating $\mathrm{LH}, \mathrm{FSH}$, and sex steroids. The pituitary remains functional, however, as peripheral administration of kisspeptin results in LH secretion (d'Anglemont de Tassigny et al., 2007; Lapatto et al., 2007).

Acknowledgments. This work was supported by the British Heart Foundation and the UK Medical Research Council [Grants PS/02/ 001, PG/09/050/27734].

\section{REFERENCES}

Adachi S, Yamada S, Takatsu Y, Matsui H, Kinoshita M, Takase K, Sugiura H, Ohtaki T, Matsumoto H, Uenoyama Y, et al. (2007) Involvement of anteroventral periventricular metastin/kisspeptin neurons in estrogen positive feedback action on luteinizing hormone release in female rats. J Reprod Dev 53:367-378.

Arai AC and Orwig N (2008) Factors that regulate KiSS1 gene expression in the hippocampus. Brain Res 1243:10-18.

Arai AC, Xia YF, Suzuki E, Kessler M, Civelli O, and Nothacker HP (2005) Cancer metastasis-suppressing peptide metastin upregulates excitatory synaptic transmission in hippocampal dentate granule cells. J Neurophysiol 94:3648-3652.

Armstrong RA, Reynolds RM, Leask R, Shearing CH, Calder AA, and Riley SC (2009) Decreased serum levels of kisspeptin in early pregnancy are associated with intra-uterine growth restriction and pre-eclampsia. Prenat Diagn 29:982-985.

Becker JA, Mirjolet JF, Bernard J, Burgeon E, Simons MJ, Vassart G, Parmentier $\mathrm{M}$, and Libert F (2005) Activation of GPR54 promotes cell cycle arrest and apoptosis of human tumor cells through a specific transcriptional program not shared by other Gq-coupled receptors. Biochem Biophys Res Commun 326:677686.

Bilban M, Ghaffari-Tabrizi N, Hintermann E, Bauer S, Molzer S, Zoratti C, Malli R, Sharabi A, Hiden U, Graier W, et al. (2004) Kisspeptin-10, a KiSS-1/metastinderived decapeptide, is a physiological invasion inhibitor of primary human trophoblasts. J Cell Sci 117:1319-1328.

Biran J, Ben-Dor S, and Levavi-Sivan B (2008) Molecular identification and functional characterization of the kisspeptin/kisspeptin receptor system in lower vertebrates. Biol Reprod 79:776-786.

Bowe JE, King AJ, Kinsey-Jones JS, Foot VL, Li XF, O'Byrne KT, Persaud SJ, and Jones PM (2009) Kisspeptin stimulation of insulin secretion: mechanisms of action in mouse islets and rats. Diabetologia 52:855-862.

Brailoiu GC, Dun SL, Ohsawa M, Yin D, Yang J, Chang JK, Brailoiu E, and Dun NJ., Chang JK, Brailoiu E, and Dun NJ (2005) KiSS-1 expression and metastin-like immunoreactivity in the rat brain. J Comp Neurol 481:314-329.

Caraty A, Smith JT, Lomet D, Ben Saïd S, Morrissey A, Cognie J, Doughton B, Baril G, Briant C, and Clarke IJ (2007) Kisspeptin synchronizes preovulatory surges in cyclical ewes and causes ovulation in seasonally acyclic ewes. Endocrinology 148: $5258-5267$.

Carrillo M, Zanuy S, Felip A, Bayarri MJ, Molés G, and Gómez A (2009) Hormonal and environmental control of puberty in perciform fish: the case of sea bass. Ann NY Acad Sci 1163:49-59.

Castaño JP, Martínez-Fuentes AJ, Gutiérrez-Pascual E, Vaudry H, Tena-Sempere M, and Malagón MM (2009) Intracellular signaling pathways activated by kisspeptins through GPR54: do multiple signals underlie function diversity? Peptides 30:10-15.

Castellano JM, Gaytan M, Roa J, Vigo E, Navarro VM, Bellido C, Dieguez C, Aguilar E, Sánchez-Criado JE, Pellicer A, Pinilla L, Gaytan F, and Tena-Sempere M., Aguilar E, Sánchez-Criado JE, Pellicer A, Pinilla L, Gaytan F, and Tena-Sempere M (2006a) Expression of KiSS-1 in rat ovary: putative local regulator of ovulation? Endocrinology 147:4852-4862.

Castellano JM, Navarro VM, Fernández-Fernández R, Castaño JP, Malagón MM, Aguilar E, Dieguez C, Magni P, Pinilla L, and Tena-Sempere M (2006b) Ontogeny and mechanisms of action for the stimulatory effect of kisspeptin on gonadotropinreleasing hormone system of the rat. Mol Cell Endocrinol 257-258:75-83.

Castellano JM, Navarro VM, Fernández-Fernández R, Nogueiras R, Tovar S, Roa J, Vazquez MJ, Vigo E, Casanueva FF, Aguilar E, et al. (2005) Changes in hypothalamic KiSS-1 system and restoration of pubertal activation of the reproductive axis by kisspeptin in undernutrition. Endocrinology 146:3917-3925.

Castellano JM, Navarro VM, Roa J, Pineda R, Sánchez-Garrido MA, García-Galiano 
D, Vigo E, Dieguez C, Aguilar E, Pinilla L, et al. (2009) Alterations in hypothalamic KiSS-1 system in experimental diabetes: early changes and functional consequences. Endocrinology 150:784-794.

Clarke IJ, Smith JT, Caraty A, Goodman RL, and Lehman MN (2009) Kisspeptin and seasonality in sheep. Peptides 30:154-163

Clarkson J, d'Anglemont de Tassigny X, Colledge WH, Caraty A, and Herbison AE (2009) Distribution of kisspeptin neurones in the adult female mouse brain. $J$ Neuroendocrinol 21:673-682.

Clarkson J and Herbison AE (2006) Postnatal development of kisspeptin neurons in mouse hypothalamus; sexual dimorphism and projections to gonadotropinreleasing hormone neurons. Endocrinology 147:5817-5825.

Clements MK, McDonald TP, Wang R, Xie G, O'Dowd BF, George SR, Austin CP, and Liu Q (2001) FMRFamide-related neuropeptides are agonists of the orphan Gprotein-coupled receptor GPR54. Biochem Biophys Res Commun 284:1189-1193.

Colledge WH (2009a) Kisspeptins and GnRH neuronal signalling. Trends Endocrinol Metab 20:115-121.

Colledge WH (2009b) Transgenic mouse models to study Gpr54/kisspeptin physiology. Peptides 30:34-41.

Curtis AE, Cooke JH, Baxter JE, Parkinson JR, Bataveljic A, Ghatei MA, Bloom SR, and Murphy KG (2010) A kisspeptin-10 analog with greater in vivo bioactivity than kisspeptin-10. Am J Physiol Endocrinol Metab 298:E296-E303.

d'Anglemont de Tassigny X, Fagg LA, Carlton MB, and Colledge WH (2008) Kisspeptin can stimulate gonadotropin-releasing hormone $(\mathrm{GnRH})$ release by a direct action at $\mathrm{GnRH}$ nerve terminals. Endocrinology 149:3926-3932.

d'Anglemont de Tassigny X, Fagg LA, Dixon JP, Day K, Leitch HG, Hendrick AG, Zahn D, Franceschini I, Caraty A, Carlton MB, et al. (2007) Hypogonadotropic hypogonadism in mice lacking a functional Kiss1 gene. Proc Natl Acad Sci USA 104:10714-10719.

de Roux N, Genin E, Carel JC, Matsuda F, Chaussain JL, and Milgrom E (2003) Hypogonadotropic hypogonadism due to loss of function of the KiSS1-derived peptide receptor GPR54. Proc Natl Acad Sci USA 100:10972-10976.

Decourt C, Tillet Y, Caraty A, Franceschini I, and Briant C (2008) Kisspeptin immunoreactive neurons in the equine hypothalamus Interactions with GnRH neuronal system. J Chem Neuroanat 36:131-137.

Dhar DK, Naora H, Kubota H, Maruyama R, Yoshimura H, Tonomoto Y, Tachibana M, Ono T, Otani H, and Nagasue N (2004) Downregulation of KiSS-1 expression is responsible for tumor invasion and worse prognosis in gastric carcinoma. Int $J$ Cancer 111:868-872.

Dhillo WS, Chaudhri OB, Patterson M, Thompson EL, Murphy KG, Badman MK, McGowan BM, Amber V, Patel S, Ghatei MA, et al. (2005) Kisspeptin-54 stimulates the hypothalamic-pituitary gonadal axis in human males. J Clin Endocrinol Metab 90:6609-6615.

Dhillo WS, Chaudhri OB, Thompson EL, Murphy KG, Patterson M, Ramachandran R, Nijher GK, Amber V, Kokkinos A, Donaldson M, et al. (2007) Kisspeptin-54 stimulates gonadotropin release most potently during the preovulatory phase of the menstrual cycle in women. J Clin Endocrinol Metab 92:3958-3966.

Dhillo WS, Savage P, Murphy KG, Chaudhri OB, Patterson M, Nijher GM, Foggo VM, Dancey GS, Mitchell H, Seckl MJ, et al. (2006) Plasma kisspeptin is raised in patients with gestational trophoblastic neoplasia and falls during treatment. Am $J$ Physiol Endocrinol Metab 291:E878-E884.

Dumalska I, Wu M, Morozova E, Liu R, van den Pol A, and Alreja M (2008) Excitatory effects of the puberty-initiating peptide kisspeptin and group I metabotropic glutamate receptor agonists differentiate two distinct subpopulations of gonadotropin-releasing hormone neurons. J Neurosci 28:8003-8013.

Dungan HM, Gottsch ML, Zeng H, Gragerov A, Bergmann JE, Vassilatis DK, Clifton DK, and Steiner RA (2007) The role of kisspeptin-GPR54 signaling in the tonic regulation and surge release of gonadotropin-releasing hormone/luteinizing hormone. J Neurosci 27:12088-12095.

Estrada KM, Clay CM, Pompolo S, Smith JT, and Clarke IJ (2006) Elevated KiSS-1 expression in the arcuate nucleus prior to the cyclic preovulatory gonadotrophinreleasing hormone/lutenising hormone surge in the ewe suggests a stimulatory role for kisspeptin in oestrogen-positive feedback. $J$ Neuroendocrinol 18:806-809

Farina A, Sekizawa A, Purwosunu Y, Rizzo N, Banzola I, Concu M, Morano D, Giommi F, Bevini M, Mabrook M, et al. (2006) Quantitative distribution of a panel of circulating mRNA in preeclampsia versus controls. Prenat Diagn 26:1115-1120.

Felip A, Zanuy S, Pineda R, Pinilla L, Carrillo M, Tena-Sempere M, and Gómez A (2008) Evidence for two distinct KiSS genes in non-placental vertebrates that encode kisspeptins with different gonadotropin-releasing activities in fish and mammals. Mol Cell Endocrinol 312:61-71.

Filby AL, van Aerle R, Duitman J, and Tyler CR (2008) The kisspeptin/gonadotropinreleasing hormone pathway and molecular signaling of puberty in fish. Biol Reprod 78:278-289.

Franceschini I, Lomet D, Cateau M, Delsol G, Tillet Y, and Caraty A (2006) Kisspeptin immunoreactive cells of the ovine preoptic area and arcuate nucleus co-express estrogen receptor alpha. Neurosci Lett 401:225-230.

Funes S, Hedrick JA, Vassileva G, Markowitz L, Abbondanzo S, Golovko A, Yang S, Monsma FJ, and Gustafson EL (2003) The KiSS-1 receptor GPR54 is essential for the development of the murine reproductive system. Biochem Biophys Res Com mun 312:1357-1363.

Gao GL, Liu LD, Zou XS, and Chen WX (2007) [Expression of KiSS-1, matrix metalloproteinase-9, nuclear factor-kappaBp65 in ovarian tumour.] Zhonghua Fu Chan Ke Za Zhi 42:34-38.

Gianetti E and Seminara S (2008) Kisspeptin and KISS1R: a critical pathway in the reproductive system. Reproduction 136:295-301.

Goldberg SF, Miele ME, Hatta N, Takata M, Paquette-Straub C, Freedman LP, and Welch DR (2003) Melanoma metastasis suppression by chromosome 6: evidence for a pathway regulated by CRSP3 and TXNIP. Cancer Res 63:432-440.

Gottsch ML, Cunningham MJ, Smith JT, Popa SM, Acohido BV, Crowley WF, Seminara S, Clifton DK, and Steiner RA (2004) A role for kisspeptins in the regulation of gonadotropin secretion in the mouse. Endocrinology 145:4073-4077.
Gottsch ML, Clifton DK, and Steiner RA (2009) From KISS1 to kisspeptins: An historical perspective and suggested nomenclature. Peptides 30:4-9.

Greives TJ, Mason AO, Scotti MA, Levine J, Ketterson ED, Kriegsfeld LJ, and Demas GE (2007) Environmental control of kisspeptin: implications for seasonal reproduction. Endocrinology 148:1158-1166.

Guan-Zhen Y, Ying C, Can-Rong N, Guo-Dong W, Jian-Xin Q, and Jie-Jun W (2007) Reduced protein expression of metastasis-related genes (nm23, KISS1, KAI1 and p53) in lymph node and liver metastases of gastric cancer. Int $J$ Exp Pathol 88:175-183.

Gutiérrez-Pascual E, Leprince J, Martínez-Fuentes AJ, Ségalas-Milazzo I, Pineda R, Roa J, Duran-Prado M, Guilhaudis L, Desperrois E, Lebreton A, et al. (2009) In vivo and in vitro structure-activity relationships and structural conformation of Kisspeptin-10-related peptides. Mol Pharmacol 76:58-67.

Han SK, Gottsch ML, Lee KJ, Popa SM, Smith JT, Jakawich SK, Clifton DK, Steiner $\mathrm{RA}$, and Herbison AE (2005) Activation of gonadotropin-releasing hormone neurons by kisspeptin as a neuroendocrine switch for the onset of puberty. $J$ Neurosci 25:11349-11356.

Harms JF, Welch DR, and Miele ME (2003) KISS1 metastasis suppression and emergent pathways. Clin Exp Metastasis 20:11-18.

Hashizume T, Saito H, Sawada T, Yaegashi T, Ezzat AA, Sawai K, and Yamashita $\mathrm{T}$ (2010) Characteristics of stimulation of gonadotropin secretion by kisspeptin-10 in female goats. Anim Reprod Sci 118:37-41.

Hata K, Dhar DK, Watanabe Y, Nakai H, and Hoshiai H (2007) Expression of metastin and a G-protein-coupled receptor (AXOR12) in epithelial ovarian cancer. European Journal of Cancer 43:1452-1459.

Hauge-Evans AC, Richardson CC, Milne HM, Christie MR, Persaud SJ, and Jones PM (2006) A role for kisspeptin in islet function. Diabetologia 49:2131-2135.

Herbison AE, de Tassigny X, Doran J, and Colledge WH (2010) Distribution and postnatal development of Gpr54 gene expression in mouse brain and gonadotropin-releasing hormone neurons. Endocrinology 151:312-321.

Hori A, Honda S, Asada M, Ohtaki T, Oda K, Watanabe T, Shintani Y, Yamada T, Suenaga M, Kitada C, et al. (2001) Metastin suppresses the motility and growth of CHO cells transfected with its receptor. Biochem Biophys Res Commun 286:958963

Horikoshi Y, Matsumoto H, Takatsu Y, Ohtaki T, Kitada C, Usuki S, and Fujino M (2003) Dramatic elevation of plasma metastin concentrations in human pregnancy: metastin as a novel placenta-derived hormone in humans. J Clin Endocrinol Metab 88:914-919.

Hou YK, Wang Y, Cong WM, and Wu MC (2007) [Expression of tumor metastasissuppressor gene KiSS-1 and matrix metalloproteinase-9 in portal vein tumor thrombus of hepatocellular carcinoma.] Ai Zheng 26:591-595.

Ikeguchi M, Hirooka Y, and Kaibara N (2003) Quantitative reverse transcriptase polymerase chain reaction analysis for KiSS-1 and orphan G-protein-coupled receptor (hOT7T175) gene expression in hepatocellular carcinoma. J Cancer Res Clin Oncol 129:531-535.

Ikeguchi M, Yamaguchi K, and Kaibara N (2004) Clinical significance of the loss of KiSS-1 and orphan G-protein-coupled receptor (hOT7T175) gene expression in esophageal squamous cell carcinoma. Clin Cancer Res 10:1379-1383.

Irwig MS, Fraley GS, Smith JT, Acohido BV, Popa SM, Cunningham MJ, Gottsch ML, Clifton DK, and Steiner RA (2004) Kisspeptin activation of gonadotropin releasing hormone neurons and regulation of KiSS-1 mRNA in the male rat. Neuroendocrinology 80:264-272.

Janneau JL, Maldonado-Estrada J, Tachdjian G, Miran I, Motté N, Saulnier P, Sabourin JC, Coté JF, Simon B, Frydman R, et al. (2002) Transcriptional expression of genes involved in cell invasion and migration by normal and tumoral trophoblast cells. J Clin Endocrinol Metab 87:5336-5339.

Jiang T, Zhang SL, Lin B, Meng LR, and Gao H (2005) Expression and clinical significance of KISS-1 and GPR54 mRNA in endometrial carcinoma. Zhonghud Zhong Liu Za Zhi 27:229-231.

Kalamatianos T, Grimshaw SE, Poorun R, Hahn JD, and Coen CW (2008) Fasting reduces KiSS-1 expression in the anteroventral periventricular nucleus (AVPV): effects of fasting on the expression of KiSS-1 and neuropeptide Y in the AVPV or arcuate nucleus of female rats. J Neuroendocrinol 20:1089-1097.

Kanda S, Akazome Y, Matsunaga T, Yamamoto N, Yamada S, Tsukamura H, Maeda $\mathrm{K}$, and Oka Y (2008) Identification of KiSS-1 product kisspeptin and steroidsensitive sexually dimorphic kisspeptin neurons in medaka (oryzias latipes). Endocrinology 149:2467-2476.

Kauffman AS, Clifton DK, and Steiner RA (2007a) Emerging ideas about kisspeptinGPR54 signaling in the neuroendocrine regulation of reproduction. Trends Neurosci 30:504-511.

Kauffman AS, Gottsch ML, Roa J, Byquist AC, Crown A, Clifton DK, Hoffman GE, Steiner RA, and Tena-Sempere M (2007b) Sexual differentiation of Kiss1 gen expression in the brain of the rat. Endocrinology 148:1774-1783.

Kauffman AS, Park JH, McPhie-Lalmansingh AA, Gottsch ML, Bodo C, Hohmann JG, Pavlova MN, Rohde AD, Clifton DK, Steiner RA, et al. (2007c) The kisspeptin receptor GPR54 is required for sexual differentiation of the brain and behavior. J Neurosci 27:8826-8835.

Keen KL, Wegner FH, Bloom SR, Ghatei MA, and Terasawa E (2008) An increase in kisspeptin-54 release occurs with the pubertal increase in luteinizing hormonereleasing hormone- 1 release in the stalk-median eminence of female rhesus monkeys in vivo. Endocrinology 149:4151-4157.

Kinoshita M, Tsukamura H, Adachi S, Matsui H, Uenoyama Y, Iwata K, Yamada S, Inoue $\mathrm{K}$, Ohtaki T, Matsumoto $\mathrm{H}$, et al. (2005) Involvement of central metastin in the regulation of preovulatory luteinizing hormone surge and estrous cyclicity in female rats. Endocrinology 146:4431-4436

Kirby H, Mead E, Maguire J, Pitkin S, Colledge W, d'Anglemont de Tassigny X, and Davenport A (2008) Kisspeptins as inotropic agents in human and mouse heart. Proc Physiol Soc 11:PC152.

Kitahashi T, Ogawa S, and Parhar IS (2009) Cloning and expression of kiss2 in the zebrafish and medaka. Endocrinology 150:821-831.

Kostadima L, Pentheroudakis G, and Pavlidis N (2007) The missing kiss of life: 
transcriptional activity of the metastasis suppressor gene KiSS1 in early breast cancer. Anticancer Res 27:2499-2504.

Kotani M, Detheux M, Vandenbogaerde A, Communi D, Vanderwinden JM, Le Poul E, Brézillon S, Tyldesley R, Suarez-Huerta N, Vandeput F, et al. (2001) The metastasis suppressor gene KiSS-1 encodes kisspeptins, the natural ligands of the orphan G protein-coupled receptor GPR54. J Biol Chem 276:34631-34636.

Kuohung W and Kaiser UB (2006) GPR54 and KiSS-1: role in the regulation of puberty and reproduction. Rev Endocr Metab Disord 7:257-263.

Kutzleb C, Busmann A, Wendland M, and Maronde E (2005) Discovery of novel regulatory peptides by reverse pharmacology: spotlight on chemerin and the RF-amide peptides metastin and QRFP. Curr Protein Pept Sci 6:265-278.

Lapatto R, Pallais JC, Zhang D, Chan YM, Mahan A, Cerrato F, Le WW, Hoffman GE, and Seminara SB (2007) Kiss1-/- mice exhibit more variable hypogonadism than Gpr54-/- mice. Endocrinology 148:4927-4936.

Lee DK, Nguyen T, O’Neill GP, Cheng R, Liu Y, Howard AD, Coulombe N, Tan CP Tang-Nguyen AT, George SR, et al. (1999) Discovery of a receptor related to the galanin receptors. FEBS Lett 446:103-107.

Lee JH, Miele ME, Hicks DJ, Phillips KK, Trent JM, Weissman BE, and Welch DR (1996) KiSS-1, a novel human malignant melanoma metastasis-suppressor gene. Journal of the National Cancer Institute 88:1731-1737.

Lee JH and Welch DR (1997a) Identification of highly expressed genes in metastasissuppressed chromosome 6/human malignant melanoma hybrid cells using subtractive hybridization and differential display. Int J Cancer 71:1035-1044.

Lee JH and Welch DR (1997b) Suppression of metastasis in human breast carcinoma MDA-MB-435 cells after transfection with the metastasis suppressor gene, KiSS-1. Cancer Res 57:2384-2387.

Lee YR, Tsunekawa K, Moon MJ, Um HN, Hwang JI, Osugi T, Otaki N, Sunakawa Y, Kim K, Vaudry H, et al. (2009) Molecular evolution of multiple forms of kisspeptins and GPR54 receptors in vertebrates. Endocrinology 150:2837-2846.

Lents CA, Heidorn NL, Barb CR, and Ford JJ (2008) Central and peripheral administration of kisspeptin activates gonadotropin but not somatotropin secretion in prepubertal gilts. Reproduction 135:879-887.

Li D, Yu W, and Liu M (2009) Regulation of KiSS1 gene expression. Peptides 30:130-138.

Li S, Ren J, Yang G, Guo Y, and Huang L (2008) Characterization of the porcine Kisspeptins receptor gene and evaluation as candidate for timing of puberty in sows. J Anim Breed Genet 125:219-227.

Liang S and Yang ZL (2007) [Expression of KiSS-1mRNA in pancreatic ductal adenocarcinoma and non-cancerous pancreatic tissues in SD rats.] Zhong Nan Da Xue Xue Bao Yi Xue Ban 32:109-113.

Liu X, Lee K, and Herbison AE (2008) Kisspeptin excites gonadotropin-releasing hormone neurons through a phospholipase C/calcium-dependent pathway regulating multiple ion channels. Endocrinology 149:4605-4614.

Magee C, Foradori CD, Bruemmer JE, Arreguin-Arevalo JA, McCue PM, Handa RJ, Squires EL, and Clay CM (2009) Biological and anatomical evidence for kisspeptin regulation of the hypothalamic-pituitary-gonadal axis of estrous horse mares. Endocrinology 150:2813-2821.

Marot D, Bieche I, Aumas C, Esselin S, Bouquet C, Vacher S, Lazennec G, Perricaudet M, Kuttenn F, Lidereau R, et al. (2007) High tumoral levels of Kiss1 and G-protein-coupled receptor 54 expression are correlated with poor prognosis of estrogen receptor-positive breast tumors. Endocr Relat Cancer 14:691-702.

Martin TA, Watkins G, and Jiang WG (2005) KiSS-1 expression in human breast cancer. Clin Exp Metastasis 22:503-511.

Masui T, Doi R, Mori T, Toyoda E, Koizumi M, Kami K, Ito D, Peiper SC, Broach JR, Oishi S, et al. (2004) Metastin and its variant forms suppress migration of pancreatic cancer cells. Biochem Biophys Res Commun 315:85-92.

Matsui H, Takatsu Y, Kumano S, Matsumoto H, and Ohtaki T (2004) Peripheral administration of metastin induces marked gonadotropin release and ovulation in the rat. Biochem Biophys Res Commun 320:383-388.

Mead EJ, Maguire JJ, Kuc RE, and Davenport AP (2007a) Kisspeptins: a multifunctional peptide system with a role in reproduction, cancer and the cardiovascular system. Br J Pharmacol 151:1143-1153.

Mead EJ, Maguire JJ, Kuc RE, and Davenport AP (2007b) Kisspeptins are novel potent vasoconstrictors in humans, with a discrete localization of their receptor, $\mathrm{G}$ protein-coupled receptor 54, to atherosclerosis-prone vessels. Endocrinology 148: $140-147$

Mechaly AS, Viñas J, and Piferrer F (2009) Identification of two isoforms of the Kisspeptin-1 receptor (kiss1r) generated by alternative splicing in a modern teleost, the Senegalese sole (Solea senegalensis). Biol Reprod 80:60-69.

Messager S (2005a) Kisspeptin and its receptor: new gatekeepers of puberty. $J \mathrm{Neu}$ roendocrinol 17:687-688.

Messager S, Chatzidaki EE, Ma D, Hendrick AG, Zahn D, Dixon J, Thresher RR, Malinge I, Lomet D, Carlton MB, et al. (2005b) Kisspeptin directly stimulates gonadotropin-releasing hormone release via $\mathrm{G}$ protein-coupled receptor 54. Proc Natl Acad Sci USA 102:1761-1766.

Miele ME, Jewett MD, Goldberg SF, Hyatt DL, Morelli C, Gualandi F, Rimessi P, Hicks DJ, Weissman BE, Barbanti-Brodano G, et al. (2000) A human melanoma metastasis-suppressor locus maps to 6q16.3-q23. Int J Cancer 86:524-528.

Miele ME, Robertson G, Lee JH, Coleman A, McGary CT, Fisher PB, Lugo TG, and Welch DR (1996) Metastasis suppressed, but tumorigenicity and local invasiveness unaffected, in the human melanoma cell line MelJuSo after introduction of human chromosomes 1 or 6. Mol Carcinog 15:284-299.

Mikkelsen JD, Bentsen AH, Ansel L, Simonneaux V, and Juul A (2009) Comparison of the effects of peripherally administered kisspeptins. Regul Pept 152:95-100.

Mitchell DC, Stafford LJ, Li D, Bar-Eli M, and Liu M (2007 Transcriptional regulation of KiSS-1 gene expression in metastatic melanoma by specificity protein-1 and its coactivator DRIP-130. Oncogene 26:1739-1747.

Mohamed JS, Benninghoff AD, Holt GJ, and Khan IA (2007) Developmental expression of the G protein-coupled receptor 54 and three GnRH mRNAs in the teleost fish cobia. J Mol Endocrinol 38:235-244.

Moon JS, Lee YR, Oh DY, Hwang JI, Lee JY, Kim JI, Vaudry H, Kwon HB, and
Seong JY (2009) Molecular cloning of the bullfrog kisspeptin receptor GPR54 with high sensitivity to Xenopus kisspeptin. Peptides 30:171-179.

Muir AI, Chamberlain L, Elshourbagy NA, Michalovich D, Moore DJ, Calamari A Szekeres PG, Sarau HM, Chambers JK, Murdock P, et al. (2001) AXOR12, a novel human $\mathrm{G}$ protein-coupled receptor, activated by the peptide KiSS-1. J Biol Chem 276:28969-28975.

Navarro VM, Castellano JM, Fernández-Fernández R, Barreiro ML, Roa J, SanchezCriado JE, Aguilar E, Dieguez C, Pinilla L, and Tena-Sempere M., Pinilla L, and Tena-Sempere M (2004a) Developmental and hormonally regulated messenger ribonucleic acid expression of KiSS-1 and its putative receptor, GPR54, in rat hypothalamus and potent luteinizing hormone-releasing activity of KiSS-1 peptide. Endocrinology 145:4565-4574.

Navarro VM, Castellano JM, Fernández-Fernández R, Tovar S, Roa J, Mayen A Barreiro ML, Casanueva FF, Aguilar E, Dieguez C, et al. (2005a) Effects of KiSS-1 peptide, the natural ligand of GPR54, on follicle-stimulating hormone secretion in the rat. Endocrinology 146:1689-1697.

Navarro VM, Castellano JM, Fernández-Fernández R, Tovar S, Roa J, Mayen A, Nogueiras R, Vazquez MJ, Barreiro ML, Magni P, et al. (2005b) Characterization of the potent luteinizing hormone-releasing activity of KiSS-1 peptide, the natural ligand of GPR54. Endocrinology 146:156-163.

Navarro VM, Castellano JM, García-Galiano D, and Tena-Sempere M (2007) Neuroendocrine factors in the initiation of puberty: the emergent role of kisspeptin. Rev Endocr Metab Disord 8:11-20.

Navarro VM, Fernández-Fernández R, Castellano JM, Roa J, Mayen A, Barreiro ML, Gaytan F, Aguilar E, Pinilla L, Dieguez C, et al. (2004b) Advanced vaginal opening and precocious activation of the reproductive axis by KiSS-1 peptide, the endogenous ligand of GPR54. J Physiol 561:379-386.

Navenot JM, Fujii N, and Peiper SC (2009a) Activation of Rho and Rho-associated kinase by GPR54 and KiSS1 metastasis suppressor gene product induces changes of cell morphology and contributes to apoptosis. Mol Pharmacol 75:1300-1306.

Navenot JM, Fujii N, and Peiper SC (2009b) KiSS1 metastasis suppressor gene product induces suppression of tyrosine kinase receptor signaling to Akt, tumor necrosis factor family ligand expression, and apoptosis. Mol Pharmacol 75:10741083.

Navenot JM, Wang Z, Chopin M, Fujii N, and Peiper SC (2005) Kisspeptin-10induced signaling of GPR54 negatively regulates chemotactic responses mediated by CXCR4: a potential mechanism for the metastasis suppressor activity of kisspeptins. Cancer Res 65:10450-10456

Niida A, Wang Z, Tomita K, Oishi S, Tamamura H, Otaka A, Navenot JM, Broach JR, Peiper SC, and Fujii N (2006) Design and synthesis of downsized metastin (45-54) analogs with maintenance of high GPR54 agonistic activity. Bioorg Med Chem Lett 16:134-137.

Nocillado JN, Levavi-Sivan B, Carrick F, and Elizur A (2007) Temporal expression of G-protein-coupled receptor 54 (GPR54), gonadotropin-releasing hormones $(\mathrm{GnRH})$, and dopamine receptor D2 (drd2) in pubertal female grey mullet, Mugil cephalus. Gen Comp Endocrinol 150:278-287.

Oakley AE, Clifton DK, and Steiner RA (2009) Kisspeptin signaling in the brain Endocr Rev 30:713-743.

Ohkura S, Takase K, Matsuyama S, Mogi K, Ichimaru T, Wakabayashi Y, Uenoyama Y, Mori Y, Steiner RA, Tsukamura H, et al. (2009) Gonadotrophin-releasing hormone pulse generator activity in the hypothalamus of the goat. $J$ Neuroendocrinol 21:813-821.

Ohtaki T, Shintani Y, Honda S, Matsumoto H, Hori A, Kanehashi K, Terao Y, Kumano S, Takatsu Y, Masuda Y, et al. (2001) Metastasis suppressor gene KiSS-1 encodes peptide ligand of a G-protein-coupled receptor. Nature 411:613-617.

Orsini MJ, Klein MA, Beavers MP, Connolly PJ, Middleton SA, and Mayo KH (2007) Metastin (KiSS-1) mimetics identified from peptide structure-activity relationship-derived pharmacophores and directed small molecule database screening. J Med Chem 50:462-471.

Pampillo M, Camuso N, Taylor JE, Szereszewski JM, Ahow MR, Zajac M, Millar RP, Bhattacharya M, and Babwah AV (2009) Regulation of GPR54 signaling by GRK2 and beta-arrestin. Mol Endocrinol 23:2060-2074.

Panidis D, Rousso D, Koliakos G, Kourtis A, Katsikis I, Farmakiotis D, Votsi E, and Diamanti-Kandarakis E (2006) Plasma metastin levels are negatively correlated with insulin resistance and free androgens in women with polycystic ovary syndrome. Fertil Steril 85:1778-1783.

Parhar IS, Ogawa S, and Sakuma Y (2004) Laser-captured single digoxigenin labeled neurons of gonadotropin-releasing hormone types reveal a novel G protein coupled receptor (Gpr54) during maturation in cichlid fish. Endocrinology 145: 3613-3618.

Paul MJ, Pyter LM, Freeman DA, Galang J, and Prendergast BJ (2009) Photic and nonphotic seasonal cues differentially engage hypothalamic kisspeptin and RFamide-related peptide mRNA expression in Siberian hamsters. $J$ Neuroendocrinol 21:1007-1014.

Pheng V, Uenoyama Y, Homma T, Inamoto Y, Takase K, Yoshizawa-Kumagaye K, Isaka S, Watanabe TX, Ohkura S, Tomikawa J, et al. (2009) Potencies of centrally or peripherally-injected full-length kisspeptin or its C-terminal decapeptide on LH release in intact male rats. $J$ Reprod Dev 55:378-382

Pielecka-Fortuna J, Chu Z, and Moenter SM (2008) Kisspeptin acts directly and indirectly to increase gonadotropin-releasing hormone neuron activity and its effects are modulated by estradiol. Endocrinology 149:1979-1986.

Pineda R, Garcia-Galiano D, Roseweir A, Romero M, Sanchez-Garrido MA, RuizPino F, Morgan K, Pinilla L, Millar RP, and Tena-Sempere M (2010) Critical roles of kisspeptins in female puberty and preovulatory gonadotropin surges as revealed by a novel antagonist. Endocrinology 151:722-730.

Plant TM, Ramaswamy S, and Dipietro MJ (2006) Repetitive activation of hypothalamic G protein-coupled receptor 54 with intravenous pulses of kisspeptin in the juvenile monkey (Macaca mulatta) elicits a sustained train of gonadotropinreleasing hormone discharges. Endocrinology 147:1007-1013

Pompolo S, Pereira A, Estrada KM, and Clarke IJ (2006) Colocalization of kisspeptin 
and gonadotropin-releasing hormone in the ovine brain. Endocrinology 147:804810 .

Qiao C, Wang CH, Shang T, and Lin QD (2005) [Clinical significance of KiSS-1 and matrix metalloproteinase-9 expression in trophoblasts of women with preeclampsia and their relation to perinatal outcome of neonates.] Zhonghua Fu Chan Ke Za Zhi 40:585-590.

Quaynor S, Hu L, Leung PK, Feng H, Mores N, Krsmanovic LZ, and Catt KJ (2007) Expression of a functional G protein-coupled receptor 54-kisspeptin autoregulatory system in hypothalamic gonadotropin-releasing hormone neurons. Mol Endocrinol 21:3062-3070.

Ramaswamy S, Gibbs RB, and Plant TM (2009) Studies of the localisation of kisspeptin within the pituitary of the rhesus monkey (Macaca mulatta) and the effect of kisspeptin on the release of non-gonadotropic pituitary hormones. J Neuroendocrinol 21:795-804.

Ramaswamy S, Guerriero KA, Gibbs RB, and Plant TM (2008) Structural interactions between kisspeptin and $\mathrm{GnRH}$ neurons in the mediobasal hypothalamus of the male rhesus monkey (Macaca mulatta) as revealed by double immunofluorescence and confocal microscopy. Endocrinology 149:4387-4395.

Ramaswamy S, Seminara SB, Pohl CR, DiPietro MJ, Crowley WF Jr, and Plant TM (2007) Effect of continuous intravenous administration of human metastin 45-54 on the neuroendocrine activity of the hypothalamic-pituitary-testicular axis in the adult male rhesus monkey (Macaca mulatta). Endocrinology 148:3364-3370.

Revel FG, Ansel L, Klosen P, Saboureau M, Pévet P, Mikkelsen JD, and Simonneaux V (2007) Kisspeptin: a key link to seasonal breeding. Rev Endocr Metab Disord 8:57-65.

Reynolds RM, Logie JJ, Roseweir AK, McKnight AJ, and Millar RP (2009) A role for kisspeptins in pregnancy: facts and speculations. Reproduction 138:1-7.

Richard N, Corvaisier S, Camacho E, and Kottler ML (2009) KiSS-1 and GPR54 at the pituitary level: overview and recent insights. Peptides 30:123-129.

Richard N, Galmiche G, Corvaisier S, Caraty A, and Kottler ML (2008) KiSS-1 and GPR54 genes are co-expressed in rat gonadotrophs and differentially regulated in vivo by oestradiol and gonadotrophin-releasing hormone. J Neuroendocrinol 20: 381-393.

Ringel MD, Hardy E, Bernet VJ, Burch HB, Schuppert F, Burman KD, and Saji M (2002) Metastin receptor is overexpressed in papillary thyroid cancer and activates MAP kinase in thyroid cancer cells. J Clin Endocrinol Metab 87:2399-2402.

Roa J, Castellano JM, Navarro VM, Handelsman DJ, Pinilla L, and Tena-Sempere M (2009) Kisspeptins and the control of gonadotropin secretion in male and female rodents. Peptides 30:57-66.

Roa J, Vigo E, García-Galiano D, Castellano JM, Navarro VM, Pineda R, Diéguez C, Aguilar E, Pinilla L, and Tena-Sempere M (2008a) Desensitization of gonadotropin responses to kisspeptin in the female rat: analyses of LH and FSH secretion at different developmental and metabolic states. Am J Physiol Endocrinol Metab 294:E1088-E1096.

Roa J, Vigo E, Castellano JM, Gaytan F, García-Galiano D, Navarro VM, Aguilar E, Dijcks FA, Ederveen AG, Pinilla L, et al. (2008b) Follicle-stimulating hormone responses to kisspeptin in the female rat at the preovulatory period: modulation by estrogen and progesterone receptors. Endocrinology 149:5783-5790.

Roa J, Vigo E, Castellano JM, Gaytan F, Navarro VM, Aguilar E, Dijcks FA, Ederveen AG, Pinilla L, van Noort PI, et al. (2008c) Opposite roles of estrogen receptor (ER)-alpha and ERbeta in the modulation of luteinizing hormone responses to kisspeptin in the female rat: implications for the generation of the preovulatory surge. Endocrinology 149:1627-1637.

Rometo AM, Krajewski SJ, Voytko ML, and Rance NE (2007) Hypertrophy and increased kisspeptin gene expression in the hypothalamic infundibular nucleus of postmenopausal women and ovariectomized monkeys. J Clin Endocrinol Metab 92:2744-2750.

Roseweir AK, Kauffman AS, Smith JT, Guerriero KA, Morgan K, Pielecka-Fortuna J, Pineda R, Gottsch ML, Tena-Sempere M, Moenter SM, et al. (2009) Discovery of potent kisspeptin antagonists delineate physiological mechanisms of gonadotropin regulation. J Neurosci 29:3920-3929.

Sanchez-Carbayo M, Belbin TJ, Scotlandi K, Prystowsky M, Baldini N, Childs G, and Cordon-Cardo C (2003) Expression profiling of osteosarcoma cells transfected with MDR1 and NEO genes: regulation of cell adhesion, apoptosis, and tumor suppression-related genes. Lab Invest 83:507-517.

Schmid K, Wang X, Haitel A, Sieghart W, Peck-Radosavljevic M, Bodingbauer M, Rasoul-Rockenschaub S, and Wrba F (2007) KiSS-1 overexpression as an independent prognostic marker in hepatocellular carcinoma: an immunohistochemical study. Virchows Arch 450:143-149.

Seminara SB (2006) Mechanisms of Disease: the first kiss-a crucial role for kisspeptin-1 and its receptor, G-protein-coupled receptor 54, in puberty and reproduction. Nat Clin Pract Endocrinol Metab 2:328-334.

Seminara SB, Dipietro MJ, Ramaswamy S, Crowley WF Jr, and Plant TM (2006) Continuous human metastin 45-54 infusion desensitizes G protein-coupled receptor 54-induced gonadotropin-releasing hormone release monitored indirectly in the juvenile male Rhesus monkey (Macaca mulatta): a finding with therapeutic implications. Endocrinology 147:2122-2126.

Seminara SB, Messager S, Chatzidaki EE, Thresher RR, Acierno JS, Jr., Shagoury JK, Bo-Abbas Y, Kuohung W, Schwinof KM, Hendrick AG, Zahn D, Dixon J, Kaiser UB, Slaugenhaupt SA, Gusella JF, O'Rahilly S, Carlton MB, Crowley WF, Jr., Aparicio SA, and Colledge WH (2003) The GPR54 gene as a regulator of puberty. $N$ Engl J Med 349:1614-1627.

Shahab M, Mastronardi C, Seminara SB, Crowley WF, Ojeda SR, and Plant TM (2005) Increased hypothalamic GPR54 signaling: a potential mechanism for initiation of puberty in primates. Proc Natl Acad Sci USA 102:2129-2134.

Shibata M, Friedman RL, Ramaswamy S, and Plant TM (2007) Evidence that down regulation of hypothalamic KiSS-1 expression is involved in the negative feedback action of testosterone to regulate luteinising hormone secretion in the adult male rhesus monkey (Macaca mulatta). J Neuroendocrinol 19:432-438.

Shirasaki F, Takata M, Hatta N, and Takehara K (2001) Loss of expression of the metastasis suppressor gene KiSS1 during melanoma progression and its association with LOH of chromosome 6q16.3-q23. Cancer Res 61:7422-7425.

Silvestre RA, Egido EM, Hernández R, and Marco J (2008) Kisspeptin-13 inhibits insulin secretion without affecting glucagon or somatostatin release: study in the perfused rat pancreas. J Endocrinol 196:283-290.

Simonneaux V, Ansel L, Revel FG, Klosen P, Pévet P, and Mikkelsen JD (2009) Kisspeptin and the seasonal control of reproduction in hamsters. Peptides 30:146-153.

Smith JT, Acohido BV, Clifton DK, and Steiner RA (2006a) KiSS-1 neurones are direct targets for leptin in the ob/ob mouse. J Neuroendocrinol 18:298-303.

Smith JT and Clarke IJ (2007) Kisspeptin expression in the brain: catalyst for the initiation of puberty. Rev Endocr Metab Disord 8:1-9.

Smith JT, Clay CM, Caraty A, and Clarke IJ (2007) KiSS-1 messenger ribonucleic acid expression in the hypothalamus of the ewe is regulated by sex steroids and season. Endocrinology 148:1150-1157.

Smith JT, Coolen LM, Kriegsfeld LJ, Sari IP, Jaafarzadehshirazi MR, Maltby M, Bateman K, Goodman RL, Tilbrook AJ, Ubuka T, et al. (2008) Variation in kisspeptin and RFamide-related peptide (RFRP) expression and terminal connections to gonadotropin-releasing hormone neurons in the brain: a novel medium for seasonal breeding in the sheep. Endocrinology 149:5770-5782.

Smith JT, Cunningham MJ, Rissman EF, Clifton DK, and Steiner RA (2005a) Regulation of Kiss1 gene expression in the brain of the female mouse. Endocrinology 146:3686-3692.

Smith JT, Dungan HM, Stoll EA, Gottsch ML, Braun RE, Eacker SM, Clifton DK, and Steiner RA (2005b) Differential regulation of KiSS-1 mRNA expression by sex steroids in the brain of the male mouse. Endocrinology 146:2976-2984.

Smith JT, Popa SM, Clifton DK, Hoffman GE, and Steiner RA (2006b) Kiss1 neurons in the forebrain as central processors for generating the preovulatory luteinizing hormone surge. J Neurosci 26:6687-6694.

Stafford LJ, Xia C, Ma W, Cai Y, and Liu M (2002) Identification and characterization of mouse metastasis-suppressor KiSS1 and its G-protein-coupled receptor. Cancer Res 62:5399-5404.

Stark AM, Tongers K, Maass N, Mehdorn HM, and Held-Feindt J (2005) Reduced metastasis-suppressor gene mRNA-expression in breast cancer brain metastases. $J$ Cancer Res Clin Oncol 131:191-198.

Stathatos N, Bourdeau I, Espinosa AV, Saji M, Vasko VV, Burman KD, Stratakis CA, and Ringel MD (2005) KiSS-1/G protein-coupled receptor 54 metastasis suppressor pathway increases myocyte-enriched calcineurin interacting protein 1 expression and chronically inhibits calcineurin activity. $J$ Clin Endocrinol Metab 90:5432-5440.

Takino T, Koshikawa N, Miyamori H, Tanaka M, Sasaki T, Okada Y, Seiki M, and Sato H (2003) Cleavage of metastasis suppressor gene product KiSS-1 protein/ metastin by matrix metalloproteinases. Oncogene 22:4617-4626.

Teles MG, Bianco SD, Brito VN, Trarbach EB, Kuohung W, Xu S, Seminara SB, Mendonca BB, Kaiser UB, and Latronico AC (2008) A GPR54-activating mutation in a patient with central precocious puberty. N Engl J Med 358:709-715.

Tena-Sempere M (2006a) GPR54 and kisspeptin in reproduction. Hum Reprod Update 12:631-639.

Tena-Sempere M (2006b) The roles of kisspeptins and G protein-coupled receptor-54 in pubertal development. Curr Opin Pediatr 18:442-447.

Terao Y, Kumano S, Takatsu Y, Hattori M, Nishimura A, Ohtaki T, and Shintani Y (2004) Expression of KiSS-1, a metastasis suppressor gene, in trophoblast giant cells of the rat placenta. Biochim Biophys Acta 1678:102-110.

Thompson EL, Amber V, Stamp GW, Patterson M, Curtis AE, Cooke JH, Appleby GF, Dhillo WS, Ghatei MA, Bloom SR, et al. (2009) Kisspeptin-54 at high dose acutely induces testicular degeneration in adult male rats via central mechanisms. $B r J$ Pharmacol 156:609-625.

Thompson EL, Murphy KG, Patterson M, Bewick GA, Stamp GW, Curtis AE, Cooke JH, Jethwa PH, Todd JF, Ghatei MA, et al. (2006) Chronic subcutaneous administration of kisspeptin-54 causes testicular degeneration in adult male rats. Am J Physiol Endocrinol Metab 291:E1074-E1082.

Thompson EL, Patterson M, Murphy KG, Smith KL, Dhillo WS, Todd JF, Ghatei MA and Bloom SR (2004) Central and peripheral administration of kisspeptin-10 stimulates the hypothalamic-pituitary-gonadal axis. J Neuroendocrinol 16:850-858.

Tomikawa J, Homma T, Tajima S, Shibata T, Inamoto Y, Takase K, Inoue N, Ohkura S, Uenoyama Y, Maeda K, et al. (2010) Molecular characterization and estrogen regulation of hypothalamic KISS1 gene in the pig. Biol Reprod 82:313-319.

Tomita K, Narumi T, Niida A, Oishi S, Ohno H, and Fujii N (2007) Fmoc-based solid-phase synthesis of GPR54-agonistic pentapeptide derivatives containing alkene- and fluoroalkene-dipeptide isosteres. Biopolymers 88:272-278.

Tomita K, Niida A, Oishi S, Ohno H, Cluzeau J, Navenot JM, Wang ZX, Peiper SC, and Fujii N (2006) Structure-activity relationship study on small peptidic GPR54 agonists. Bioorg Med Chem 14:7595-7603.

Tomita K, Oishi S, Ohno H, and Fujii N (2008) Structure-activity relationship study and NMR analysis of fluorobenzoyl pentapeptide GPR54 agonists. Biopolymers 90:503-511.

van Aerle R, Kille P, Lange A, and Tyler CR (2008) Evidence for the existence of a functional Kiss1/Kiss1 receptor pathway in fish. Peptides 29:57-64.

Vanhoutte PM, Humphrey PP, and Spedding M (1996) X. International Union of Pharmacology recommendations for nomenclature of new receptor subtypes. Pharmacol Rev 48:1-2.

Wacker JL, Feller DB, Tang XB, Defino MC, Namkung Y, Lyssand JS, Mhyre AJ, Tan X, Jensen JB, and Hague C (2008) Disease-causing mutation in GPR54 reveals the importance of the second intracellular loop for class A G-proteincoupled receptor function. J Biol Chem 283:31068-31078.

Wagner GC, Johnston JD, Clarke IJ, Lincoln GA, and Hazlerigg DG (2008) Redefining the limits of day length responsiveness in a seasonal mammal. Endocrinology 149:32-39.

Welch DR, Chen P, Miele ME, McGary CT, Bower JM, Stanbridge EJ, and Weissman BE (1994) Microcell-mediated transfer of chromosome 6 into metastatic human C8161 melanoma cells suppresses metastasis but does not inhibit tumorigenicity. Oncogene 9:255-262. 
West A, Vojta PJ, Welch DR, and Weissman BE (1998) Chromosome localization and genomic structure of the KiSS-1 metastasis suppressor gene (KISS1). Genomics 54:145-148.

Yan C, Wang H, and Boyd DD (2001) KiSS-1 represses 92-kDa type IV collagenase expression by down-regulating NF-kappa B binding to the promoter as a consequence of Ikappa Balpha -induced block of p65/p50 nuclear translocation. J Biol Chem 276:1164-1172.

Yang B, Jiang Q, Chan T, Ko WK, and Wong AO (2010) Goldfish kisspeptin molecular cloning, tissue distribution of transcript expression, and stimulatory effects on prolactin, growth hormone and luteinizing hormone secretion and gene expression via direct actions at the pituitary level. Gen Comp Endocrinol 165: $60-71$.
Yao HL, Yang ZL, Li YG, and Liu GW (2007) [In situ hybridization study on the expression of Kiss-1 and KAI-1 metastasis suppressor genes in gastric cancer.] Zhonghua Wei Chang Wai Ke Za Zhi 10:274-277.

Zhang C, Roepke TA, Kelly MJ, and Rønnekleiv OK (2008) Kisspeptin depolarizes gonadotropin-releasing hormone neurons through activation of TRPC-like cationic channels. J Neurosci 28:4423-4434.

Zhang SL, Yu Y, Jiang T, Lin B, and Gao H (2005) [Expression and significance of KiSS-1 and its receptor GPR54 mRNA in epithelial ovarian cancer.] Zhonghua Fu Chan Ke Za Zhi 40:689-692.

Zohrabian VM, Nandu H, Gulati N, Khitrov G, Zhao C, Mohan A, Demattia J, Braun A, Das K, Murali R, et al. (2007) Gene expression profiling of metastatic brain cancer. Oncol Rep 18:321-328. 